\title{
The GEOVIDE cruise in May-June 2014 reveals an intense Meridional Overturning Circulation over a cold and fresh subpolar North Atlantic
}

\author{
Patricia Zunino $^{1}$, Pascale Lherminier ${ }^{1}$, Herlé Mercier $^{2}$, Nathalie Daniault ${ }^{2}$, Maribel I. García-Ibáñez ${ }^{3}$, and \\ Fiz F. Pérez ${ }^{3}$ \\ ${ }^{1}$ Ifremer, Univ. Brest, CNRS, IRD, Laboratoire d'Océanographie Physique et Spatiale (LOPS), \\ IUEM, 29280, Plouzané, France \\ ${ }^{2}$ CNRS, Ifremer, Univ. Brest, IRD, Laboratoire d'Océanographie Physique et Spatiale (LOPS), \\ IUEM, 29280, Plouzané, France \\ ${ }^{3}$ Instituto de Investigaciones Marinas, IIM-CSIC, 36208 Vigo, Spain \\ Correspondence to: Patricia Zunino (pzuninor@ifremer.fr)
}

Received: 7 July 2017 - Discussion started: 13 July 2017

Revised: 2 November 2017 - Accepted: 5 November 2017 - Published: 29 November 2017

\begin{abstract}
The GEOVIDE cruise was carried out in the subpolar North Atlantic (SPNA) along the OVIDE section and across the Labrador Sea in May-June 2014. It was planned to clarify the distribution of the trace elements and their isotopes in the SPNA as part of the GEOTRACES international program. This paper focuses on the state of the circulation and distribution of thermohaline properties during the cruise. In terms of circulation, the comparison with the 2002-2012 mean state shows a more intense Irminger Current and also a weaker North Atlantic Current, with a transfer of volume transport from its northern to its central branch. However, those anomalies are compatible with the variability already observed along the OVIDE section in the 2000s. In terms of properties, the surface waters of the eastern SPNA were much colder and fresher than the averages over 2002-2012. In spite of negative temperature anomalies in the surface waters, the heat transport across the OVIDE section estimated at $0.56 \pm 0.06 \mathrm{PW}$ was the largest measured since 2002 . This relatively large value is related to the relatively strong Meridional Overturning Circulation measured across the OVIDE section during GEOVIDE $(18.7 \pm 3.0 \mathrm{~Sv})$. By analyzing the air-sea heat and freshwater fluxes over the eastern SPNA in relation to the heat and freshwater content changes observed during 2013 and 2014, we concluded that on a short timescale these changes were mainly driven by air-sea heat and freshwater fluxes rather than by ocean circulation.
\end{abstract}

\section{Introduction}

The subpolar North Atlantic (SPNA) is a key area for studying the effect of climate change in the ocean. The deep convection processes there behave as a driving mechanism for the Meridional Overturning Circulation (Kuhlbrodt et al., 2007; Rhein et al., 2011; Sarafanov et al., 2012), which transports heat to high latitudes in the North Atlantic and is predicted to slow down at the end of the present century (IPCC, 2007). Additionally, the SPNA presents the highest anthropogenic $\mathrm{CO}_{2}$ storage rate of all oceans (Khatiwala et al., 2013) due to both the advection of surface waters enriched with anthropogenic $\mathrm{CO}_{2}$ in the subtropical North Atlantic (Pérez et al., 2013; Zunino et al., 2015) and their deep injection in the subpolar gyre (Pérez et al., 2010). In addition, the SPNA is one of the few oceanic regions where significant cooling was detected over 1955-2010 while the rest of the world oceans were warming (Levitus et al., 2012). For all these reasons, the SPNA has been the target of several projects and broadly sampled by oceanographic cruises. As part of the OVIDE project (http://www.umr-lops.fr/Projets/ Projets-actifs/OVIDE), the OVIDE section has been sampled biennially in summer since 2002 to collect data related to the circulation and the carbon cycle. Its path between Greenland and Portugal is shown in Fig. 1 along with a schematic view of the upper, intermediate, and deep circulations in the SPNA 
adapted from Daniault et al. (2016), which will be referred to as D2016 hereafter.

The international GEOTRACES program (http://www. geotraces.org/) aims to characterize the trace elements and their isotopes (TEIs) in the world oceans. These TEIs are Fe, $\mathrm{Al}, \mathrm{Zn}, \mathrm{Mn}, \mathrm{Cd}, \mathrm{Cu}, \delta^{15} \mathrm{~N}, \delta{ }^{13} \mathrm{C},{ }^{231} \mathrm{~Pa} /{ }^{230} \mathrm{Th}, \mathrm{Pb}$, and $\mathrm{Nd}$ in the dissolved phase and in particles and aerosols. TEIs provide constraints and flux estimates that can be used to reconstruct past environmental conditions. The GEOVIDE project is a French contribution to the GEOTRACES program. It is dedicated to measuring the large-scale distributions of TEIs in the SPNA for the first time. The GEOVIDE cruise was carried out in May-June 2014 and was composed of two sections: one along the OVIDE line (its seventh repetition) and another one crossing the Labrador Sea from Cape Farewell (Greenland) to St. John's (Canada). The expertise gained on water mass properties and circulation across the OVIDE section (García-Ibáñez et al., 2015; D2016) helped to determine the optimal geographic distribution of the TEI sampling. However, the ocean is not steady, and the present study shows how anomalous in terms of thermohaline properties and circulation the eastern SPNA was in summer 2014 compared with the previous decade and thus provides guidance for the interpretation of the measured distribution of TEIs.

The ocean has taken up $90 \%$ of the heat accumulated in the climate system since 1971 (Riser et al., 2016). In this context, it is striking to note the absence of a significant warming trend in between 50 and $60^{\circ} \mathrm{N}$ in the Atlantic Ocean between 1955 and 2010 (Levitus et al., 2012; Sgubin et al., 2017). In fact, an important variability in the heat and freshwater content occurs in the SPNA on decadal or longer timescales. Since 1960, different periods of cooling (warming) or freshening (salinification) in the SPNA have been detected. Negative salinity anomalies were observed in the SPNA surface waters during the 1970s, referred to as a great salinity anomaly event. They were explained by a large pulse of freshwater getting into the SPNA through the Denmark Strait (Dickson et al., 1988; Robson et al., 2014). Concurrently, the subpolar gyre (SPG) started a cold phase that persisted up to the beginning of the 1990s. Later, from the mid-1990s to the mid-2000s, positive anomalies of temperature and salinity in the surface waters of the SPNA were observed, coinciding with the contraction and weakening of the SPG (e.g., Bersch, 2002, 2007; Sarafanov et al., 2008; Häkkinen et al., 2011). Many studies examined the causes of the observed decadal to multi-decadal variability in ocean heat content in the SPNA through the analysis of both observations and model outputs (e.g., Deshayes and Frankignoul, 2008; Lohmann et al., 2009; Robson et al., 2012, 2014; Barrier et al., 2015). They concluded that the heat content anomalies in the SPNA on a long timescale are mainly controlled by changes in the lateral advection linked to changes in the intensity of the Atlantic Meridional Overturning Circulation (AMOC). In a shorter period of time, the air-sea flux causes significant heat and freshwater changes by intensifying or buffering the effect of the anomalies caused by the lateral advection (Barrier et al., 2015; Desbruyères et al., 2015; Grist et al., 2015).

Recently, Hermanson et al. (2014) and Robson et al. $(2016,2017)$ analyzed the outputs of coupled climate models and identified a new cooling and freshening period from the mid-2000s. Their results coincide with observations: Johnson et al. (2016) documented an SPNA region cooler in 2014 than in 1993-2014 climatology, and this cooling intensified in 2015 and 2016 (Yashayaev and Loder, 2016, 2017). Over the eastern SPNA, Grist et al. (2015) analyzed the winter 2014 anomalous air-sea fluxes and their imprint on the ocean. Based on EN4 ocean reanalysis, they detected negative temperature anomalies in the surface waters, which they related to anomalous air-sea heat fluxes. Conversely, Holliday et al. (2015), who found evidence of similar cooling and freshening in the Iceland basins from 2010-2011 to 2014, hypothesized a remote source of those anomalies, writing that "the eastern SPNA is once again being influenced by cold, fresh western subpolar water". We will discuss both hypotheses in this study.

In this paper, we first contextualize the physical background of the GEOVIDE cruise to help in the interpretation of the distribution of TEIs in the eastern SPNA. Other work dealing with TEI distribution is also published in this Biogeosciences GEOVIDE Special Issue: Cossa et al. (2017), Lemaître et al. (2017), García-Ibáñez et al. (2017), and others. Subsequently, through the analysis of the GEOVIDE cruise data along with altimetry, oceanic database, and airsea flux data, we disentangle the causes of the anomalous thermohaline properties of the surface and intermediate layers of the eastern SPNA in May-June 2014. The paper is organized as follows. Data and methodology are described in Sect. 2. Section 3 displays the main results on the large-scale and mesoscale patterns of the circulation and thermohaline anomalies in 2014, setting the GEOVIDE TEI stations in this context. These results are discussed in Sect. 4. Finally, Sect. 5 presents the main conclusions.

\section{Data and methods}

\subsection{GEOVIDE data}

The GEOVIDE cruise (Lherminier and Sarthou, 2017) was the French contribution to the GEOTRACES program (http:// www.geotraces.org/) in the North Atlantic. It was carried out onboard the French R/V Pourquoi Pas? from 15 May 2014 to 30 June 2014. A total of 78 stations were measured and sampled along two hydrographic sections: (i) the seventh repetition of the OVIDE section (from Portugal to Greenland (http://www.umr-lops.fr/Projets/Projets-actifs/OVIDE) and (ii) a section across the southern Labrador Sea between Cape Farewell and Newfoundland. In this paper we only deal 


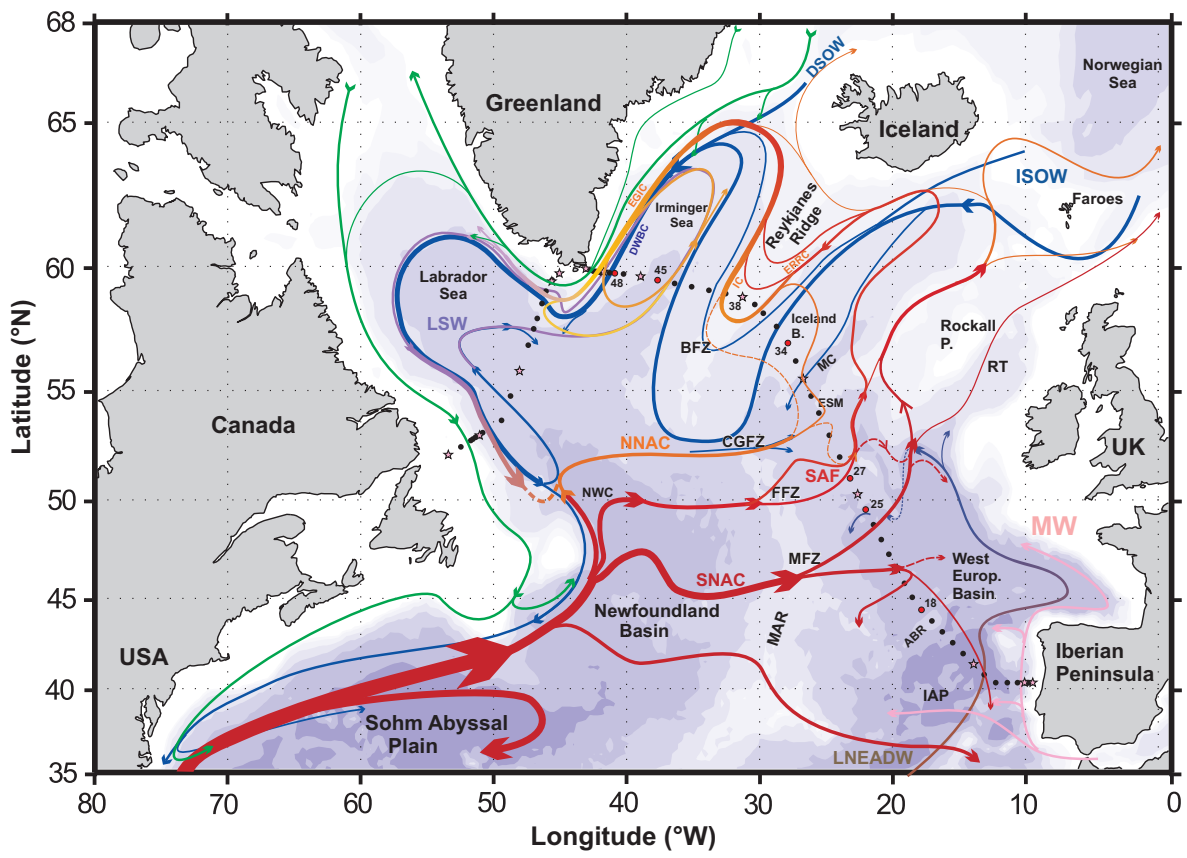

Figure 1. Schematic diagram of the 2002-2012 mean large-scale circulation adapted from Daniault et al. (2016). Bathymetry is plotted in color with color changes at 100 and $1000 \mathrm{~m}$ and every $1000 \mathrm{~m}$ below $1000 \mathrm{~m}$. The locations of the GEOVIDE hydrographic stations are indicated by black dots along the OVIDE section and across the Labrador Sea. Red dots and associated numbers along the OVIDE section show the stations delimiting the regions used in this paper for the transport computations of the different currents crossing the OVIDE section. The names of the main currents are indicated in the figure: East Greenland-Irminger Current (EGIC), Deep Western Boundary Current (DWBC), Irminger Current (IC), Eastern Reykjanes Ridge Current (ERRC), the northern branch of the North Atlantic Current (NNAC), Subarctic Front (SAF), and the southern branch of the North Atlantic Current (SNAC). Super stations and XL stations established during GEOVIDE are represented by pink stars. The main topographical features of the subpolar North Atlantic are labeled: Azores-Biscay Rise (ABR), Bight Fracture Zone (BFZ), Charlie-Gibbs Fracture Zone (CGFZ), Faraday Fracture Zone (FFZ), Maxwell Fracture Zone (MFZ), Mid-Atlantic Ridge (MAR), Iberian Abyssal Plain (IAP), Northwest Corner (NWC), Rockall Trough (RT), Rockall Plateau (Rockall P.), and Maury Channel (MC). The main water masses are indicated: Denmark Strait Overflow Water (DSOW), Iceland-Scotland Overflow Water (ISOW), Labrador Sea Water (LSW), Mediterranean Water (MW), and lower Northeast Atlantic Deep Water (LNEADW).

with data from the OVIDE section. Because this cruise was inserted into the GEOTRACES project, a large number of parameters were measured, some of them present in the ocean in very low concentrations. Therefore, several rosette casts (up to nine) had to be done at some stations; the full-depth cast with salinity and oxygen samples was always used for the physical characterization of water masses and currents. Stations were named according to the parameters to be measured and the different number of casts to be carried out: short, large, XL, and super stations. Nearly all the TEIs required by the GEOTRACES program were sampled at XL and super stations, the positions of which were selected to be representative of the different hydrographic regions, as detailed in Sect. 3.4. Because the ship time was limited to 45 days, the number of stations along the OVIDE section was reduced compared with previous cruises, with 60 stations within 6 weeks during GEOVIDE compared with 95 stations usually sampled within about 3 weeks in previous OVIDE cruises.
Conductivity, temperature, pressure, and dissolved oxygen were measured using a CTD SBE 911 equipped with an SBE 43. The rosette was also equipped with 22 bottles for collecting seawater. For calibration purposes, salinity and oxygen were determined onboard from seawater samples using a salinometer and titration, respectively. The final accuracies were $0.001{ }^{\circ} \mathrm{C}, 0.002$, and $2 \mu \mathrm{mol} \mathrm{kg}{ }^{-1}$ for temperature, salinity, and oxygen, respectively. Figure 2 shows the calibrated temperature, salinity, and oxygen measured during CTD-O ${ }_{2}$ down casts of the OVIDE section. For more details about the water mass properties and their distributions along the OVIDE section between 2002 and 2012, see García-Ibáñez et al. (2015) and D2016. Finally, the velocities of the upper waters were measured continuously with two ship-mounted ADCPs (ocean surveyors) at frequencies of 38 and $150 \mathrm{~Hz}$ measuring down to 1000 and $300 \mathrm{~m}$ with vertical resolutions of 24 and $8 \mathrm{~m}$, respectively.

The winter mixed layer depth (WMLD) was estimated along the OVIDE section by visual inspection of the individual potential density and apparent oxygen utilization (AOU) 

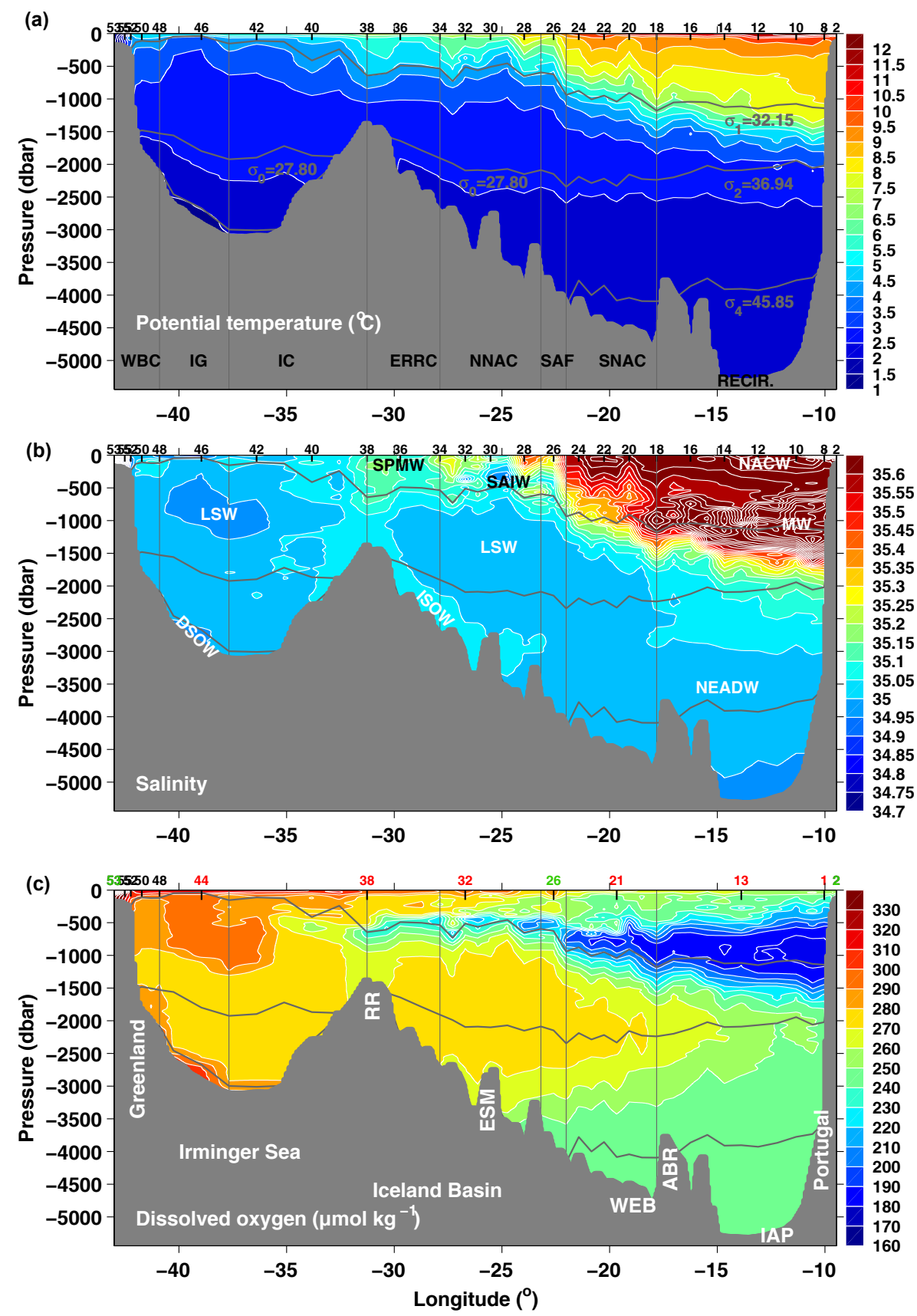

Figure 2. Vertical section of potential temperature $\left({ }^{\circ} \mathrm{C}\right)$, salinity, and oxygen $\left(\mu \mathrm{mol} \mathrm{kg}{ }^{-1}\right)$ along the OVIDE section measured during the GEOVIDE cruise. The horizontal gray lines in the three plots represent the isopycnal layers $\left(\sigma_{1}=32.15, \sigma_{0}=27.80 \mathrm{~kg} \mathrm{~m}^{-3}\right.$ or $\sigma_{2}=36.94$, $\sigma_{4}=45.85 \mathrm{~kg} \mathrm{~m}^{-3}$ ) indicated in panel (a). The vertical gray lines in the three plots are the limits between the different circulation components crossing the OVIDE section: Western Boundary Current (WBC), Irminger Gyre (IG), Irminger Current (IC), Eastern Reykjanes Ridge Current (ERRC), northern branch of the North Atlantic Current (NNAC), Subarctic Front (SAF), southern branch of the North Atlantic Current (SNAC), and the recirculation in the Iberian Abyssal Plain (RECIR). The main water masses are indicated in panel (b): Denmark Strait Overflow Water (DSOW), Iceland-Scotland Overflow Water (ISOW), Labrador Sea Water (LSW), subpolar mode water (SPMW), Subarctic Intermediate Water (SAIW), North Atlantic Central Water (NACW), Mediterranean Water (MW), and Northeast Atlantic Deep Water (NEADW). The main topographic features are indicated in panel (c): Reykjanes Ridge (RR), Eriador Seamount (ESM), Western European Basin (WEB), Azores-Biscay Rise (ABR), and Iberian Abyssal Plain (ABP). Ticks at the top of panels (a) and (b) indicate the positions of all the stations measured during GEOVIDE along the OVIDE section, with station numbers given above. In panel (c), the red and green numbers indicate the position of the super stations and XL stations, respectively. 
profiles measured during the GEOVIDE cruise. Because the cruise was conducted in summer, the seasonal mixed layer was disregarded and the WMLD was defined as the depth at which the slope of the density profile was accentuated and the AOU was larger than $0.6 \mu \mathrm{mol} \mathrm{kg}{ }^{-1}$. The latter value was chosen because it was the best fit with the density criteria at most stations.

\subsection{Inverse model}

The absolute geostrophic field orthogonal to the section was estimated with a box inverse model using the hydrographic profiles measured at each station, the current measured by the ship ADCP (S-ADCP), and a volume conservation constraint of $1 \mathrm{~Sv}$ northward (Lherminier et al., 2007). For inversion constraint, the S-ADCP data were averaged between stations in layers where the shear of the velocity profile was consistent with geostrophic velocity profiles. The inverse model is based on the thermal wind equation and the least-squares formalism following the method described in Mercier et al. (1986) and Lux et al. (2001). Additionally, the Ekman velocities were added to the inverse model: the Ekman transport was estimated from NCEP winds (Kalnay et al., 1996) and equally distributed over the first $30 \mathrm{~m}$. The velocity errors were given by the resulting covariance matrix from the box inverse model. For more details about the inverse model configuration specific to OVIDE, see Lherminier et al. $(2007,2010)$ and Gourcuff et al. (2011). The volume transports were computed by multiplying velocities by the distances between two stations. Their errors were obtained from the full covariance matrix of velocities, taking into account error correlations as explained in Mercier (1986).

For the computation of transport across the OVIDE section from GEOVIDE data, the first challenge was to determine the proper spatial subsampling. In order to select the station positions and minimize the error associated with the subsampling, a sensitivity analysis was performed with the data from the 2010 OVIDE cruise before the GEOVIDE cruise was carried out. The chosen compromise was efficient to represent all the main water masses and gave similar AMOC amplitude and consistent transports of the currents crossing the section, although the errors in the 2010 regional features increased when subsampled. However, in 2014 we used a more precise S-ADCP, reducing the S-ADCP error contribution to the inverse model solution. Consequently, the final errors of the dynamical structures in 2014 are of the same order of magnitude as the errors estimated in previous OVIDE cruises.

The velocities measured by the S-ADCP and those resulting from the inverse model are compared in Fig. 3 (note that the vertical scale differs between the subplots). We see that the inverse model results reproduce the main features of the large-scale circulation captured by the S-ADCP. As expected, mesoscale and ageostrophic structures of horizontal sizes smaller than the distances between stations are visible on the S-ADCP section but are not resolved in the inverse model solution (e.g., between stations 45 and 38 or between stations 32 and 27). However, because the geostrophic velocity is an average between stations, this does not imply any bias in the transports. This outcome is also supported by Gourcuff et al. (2011), who compared altimetry and S-ADCP data and showed that the contributions of ageostrophic motions tend to cancel out when averaged over the distance between stations.

The inverse model estimates the absolute geostrophic transport and the transport of heat and other tracers. The under-sampling of the GEOVIDE cruise notably increases the errors associated with the transport of tracers because the horizontal gradients of those tracers are less well resolved. The tracer considered in this work is temperature. By applying the GEOVIDE subsampling to the inversion of the OVIDE 2010 data, we estimated a supplementary and independent sampling error of $0.04 \mathrm{PW}$ for heat transport.

\subsection{Oceanic database}

We used the in situ analysis system (ISAS; Gaillard et al., 2016), which based on Argo profiles and other qualified in situ observations (cruises, fixed-point time series, ships of opportunity, etc.) produced monthly gridded fields of temperature and salinity profiles by using optimal interpolation for the period since 2002. We also used EN4 reanalysis. Similar to ISAS, EN4 reanalysis is an optimal interpolation that incorporates in situ data measured since 1900, filling gaps by extrapolation from the observational data using covariances from the Hadley Centre model (Good et al., 2013). We also used the temperature and salinity analysis developed by JAMSTEC (Hosoda et al., 2008), which is also an optimal interpolation based on Argo profiles, the Triangle Trans-Ocean Buoy Network (TRITON), and other in situ observations.

First, we evaluated the temporal and horizontal extension of the potential temperature $(\theta)$ and salinity $(S)$ anomalies detected in the surface layer from ISAS: both properties were averaged between 20 and $500 \mathrm{~m}$ at each ISAS grid point in the North Atlantic, and monthly anomalies were then estimated with respect to the 2002-2012 mean values. Second, the ISAS, EN4, and JAMSTEC databases were used to evaluate the heat and freshwater content changes in the upper $1000 \mathrm{~m}$ in the region delimited by $40-60^{\circ} \mathrm{N}$ and $45-10^{\circ} \mathrm{W}$ : for each month the heat content $\left(\mathrm{HC}_{\mathrm{month}}\right)$ and the freshwater content $\left(\mathrm{FWC}_{\mathrm{month}}\right)$ of the volume of water in the box previously defined was estimated following Eqs. (1) and (2), respectively:

$\mathrm{HC}_{\text {month }}=\sum_{z=1}^{z=n} \sum_{i=1}^{i=m} \theta_{z, i} \cdot \mathrm{Cp}_{z, i} \cdot \rho_{z, i} \cdot V_{z, i}$,
$\mathrm{FWC}_{\text {month }}=\sum_{z=1}^{z=n} \sum_{i=1}^{i=m} \frac{\left(35-S_{z, i}\right) \cdot V_{z, i}}{35}$,

where $z$ and $i$ are the depth levels and grid points of the database, and $\mathrm{Cp}_{z, i}, \rho_{z, i}$, and $V_{z, i}$ are the heat content capacity, density, and volume of each depth level and grid point of the database. 


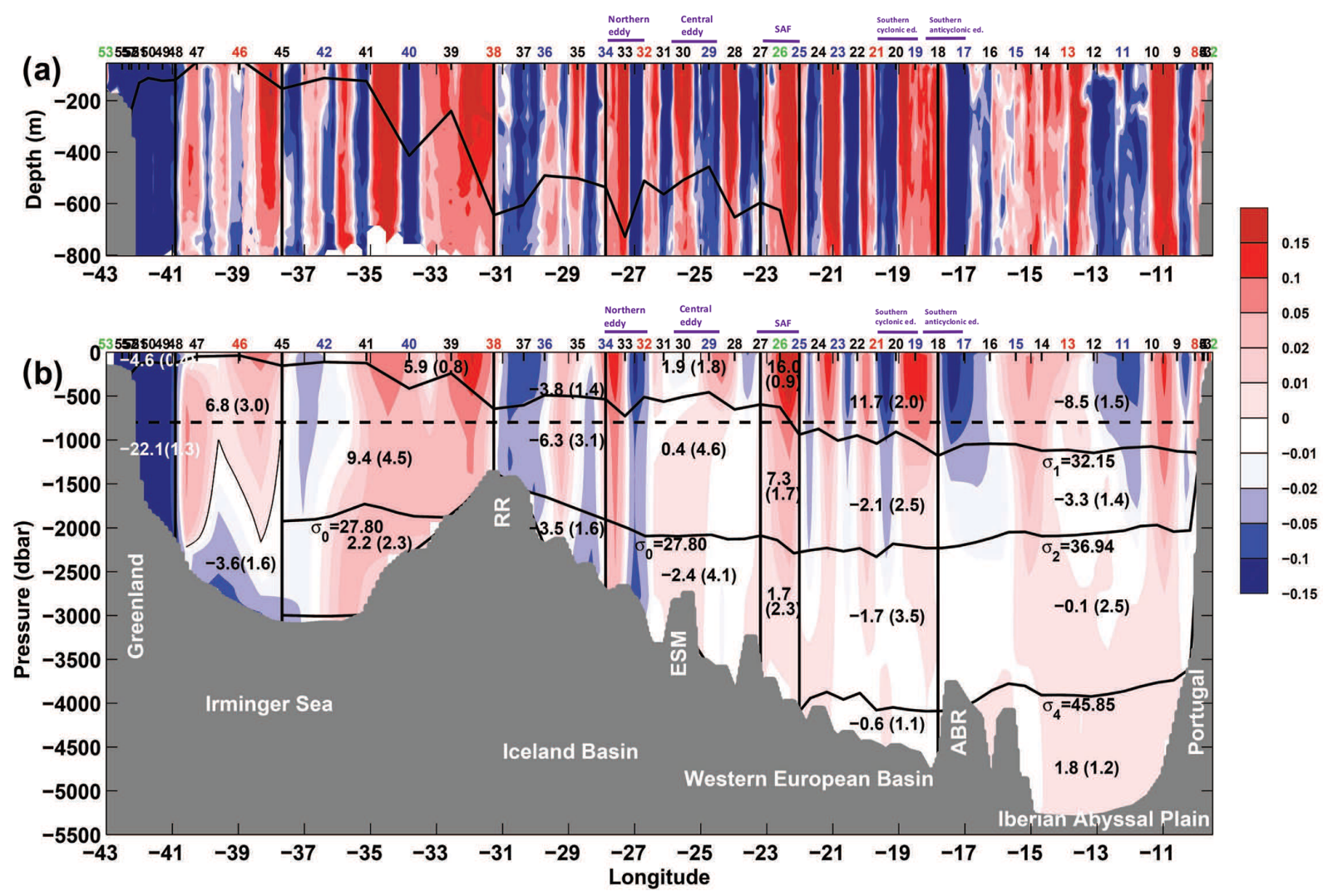

Figure 3. Velocities $\left(\mathrm{m} \mathrm{s}^{-1}\right)$ orthogonal to the OVIDE section measured during the GEOVIDE cruise. Positive or negative values indicate northeastward or southwestward velocities. (a) Velocities measured by the ship ADCP. (b) Geostrophic velocity obtained by the inversion model plus Ekman velocities in the upper $30 \mathrm{~m}$. The vertical black lines are the limits between the different circulation components crossing the OVIDE section as defined in the main text and at the bottom of Fig. 2a. The horizontal discontinuous black line delimits the 800 dbar for comparison of panels (a) and (b). The horizontal black continuous lines are the isopycnals $\sigma_{1}=32.15, \sigma_{0}=27.80$ or $\sigma_{2}=36.94$ and $\sigma_{4}=45.85 \mathrm{~kg} \mathrm{~m}^{-3}$. The bold numbers inside the figure are the volume transports (in $\mathrm{Sv}$ ) estimated for each region and vertical layer, with errors in parentheses. The only exception is the estimation of the IG transport, which following Väge et al. (2011) was computed as the northward transport (the $0 \mathrm{~m} \mathrm{~s}^{-1}$ isotach is indicated as a thin black line in panel (b) in the western Irminger Sea). The station numbers at the top of the figure are color coded: black for regular stations, blue for large stations, green for XL stations, and red for super stations. The eddies described in Sect. 3.2 are indicated at the top of the plots.

\subsection{Air-sea flux data}

In order to evaluate the role of atmospheric forcing on the $\theta$ and $S$ anomalies observed during the GEOVIDE cruise, reanalyzed ERA-Interim data (Berrisford et al., 2011) and NCEP data (Kanamitsu et al., 2002, http://www.esrl.noaa.gov/psd/) were processed. In particular, we estimated seasonal anomalies of net air-sea heat flux (and its components: sensible heat, latent heat, net longwave radiation, and net shortwave radiation) and freshwater flux (and its components: precipitation and evaporation) as follows. Firstly, seasonal means were computed by defining winter as DJF, spring as MAM, summer as JJA, and autumn as SON. Secondly, seasonal anomalies were calculated relative to the mean seasonal cycle of 2002-2012. Finally, the anomalies of winter-spring 2014 that preceded the GEOVIDE cruise were estimated.
Furthermore, the monthly time series of net air-sea heat and freshwater fluxes were used to evaluate the contribution of the atmospheric forcing to the observed heat and freshwater content changes in the box defined in Sect. 2.3. Specifically, we integrated the net air-sea heat and freshwater fluxes given every $12 \mathrm{~h}$ in ERA-INTERIM and $6 \mathrm{~h}$ in NCEP from 16 January 2013 to 15 December 2014 . The resulting time series were compared with the monthly time series of heat and freshwater content change between one month and the previous month accumulated from January 2013 to December 2014. 

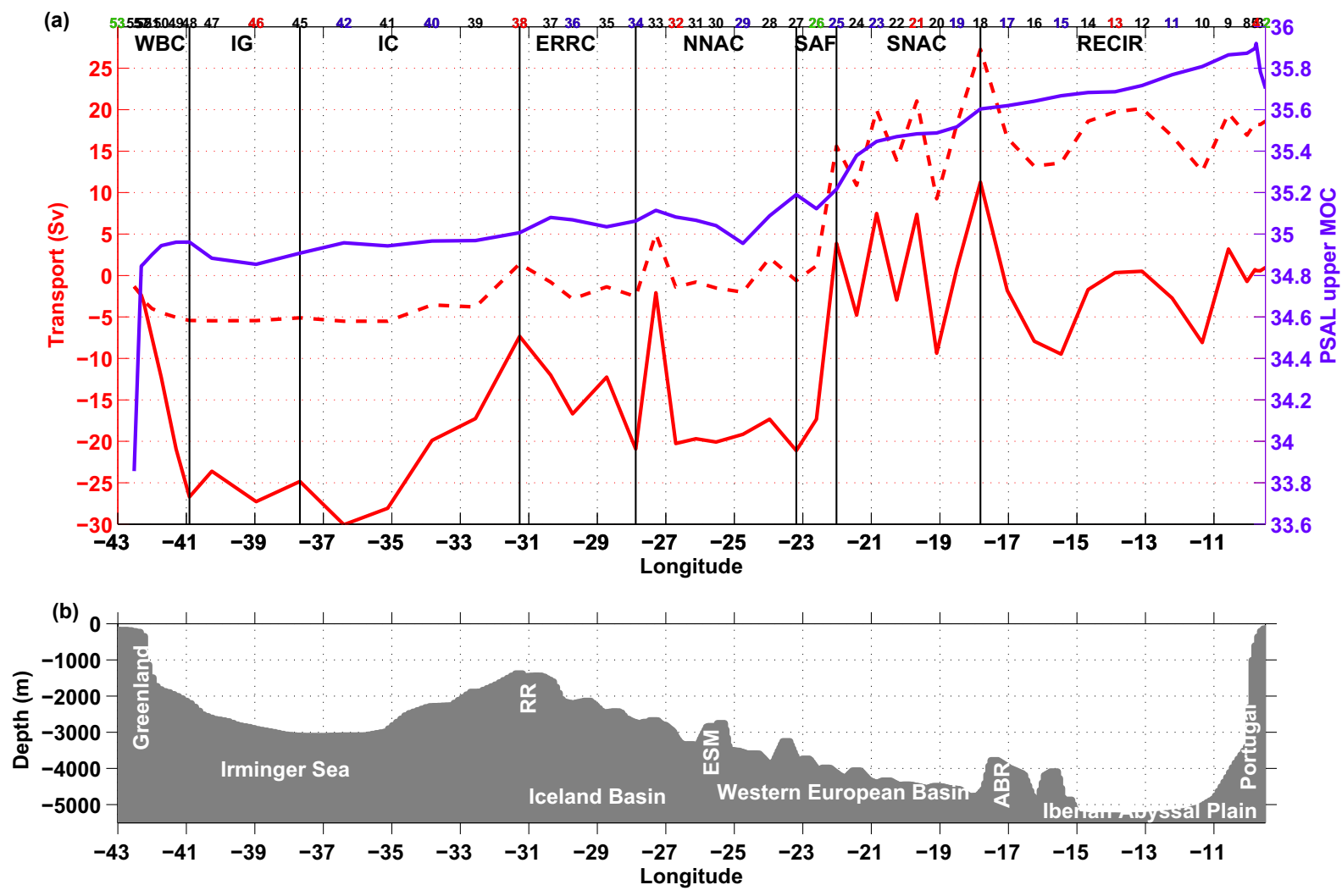

Figure 4. (a) Stream function or volume transport horizontally accumulated from Greenland to each GEOVIDE station down to Portugal and vertically accumulated in the upper limb of the MOC (red discontinuous line) and in the whole water column (red continuous line). The mean salinity in the upper limb of the MOC is also shown by the blue line and labeled on the right-hand axis. Acronyms at the top of the figure indicate the different components of the circulation crossing the OVIDE section as defined in Fig. 2. See Fig. 3 for station numbers and bathymetry legend. (b) Bathymetry along the OVIDE section; acronyms as in Fig. 2.

\section{Results}

\subsection{Circulation across the OVIDE section in 2014}

The OVIDE section is intersected by permanent currents and gyres that are described by D2016 using the average measurements from the first six OVIDE cruises (2002-2012). This section presents the intensity, location, and extension of these dynamical structures during the GEOVIDE cruise. The results shown hereafter are based on the solution of the inverse model (see Fig. 3b). Despite the mesoscale structures typical of a single occupation of the section, we can identify and quantify all the main patterns described by D2016.

Near Greenland, the water flowing southwestward guided by the continental slope is the Western Boundary Current (WBC): it has two components, the East Greenland-Irminger Current (EGIC $\sigma_{0}<27.8 \mathrm{~kg} \mathrm{~m}^{-3}$ ) and the Deep Western Boundary Current (DWBC, $\sigma_{0}>27.8 \mathrm{~kg} \mathrm{~m}^{-3}$ ). During the GEOVIDE cruise, the extension of the DWBC towards the central Irminger Sea at depths $>2000 \mathrm{~m}$ (see Fig. 3b) is marked by a bottom mesoscale feature typical of the plume structure of the overflow (Spall and Price, 1997). The total intensity of the WBC was estimated at $30.3 \pm 2.1 \mathrm{~Sv}$ southward.

The cyclonic gyre defined as the Irminger Gyre (IG) by Väge et al. (2011) can be seen in the western part of the central Irminger Sea. Following their definition, we quantified the intensity of the IG by integrating the northward transport above the isotach $0 \mathrm{~m} \mathrm{~s}^{-1}$ (Fig. 3b), which amounted to $6.8 \pm 3.0 \mathrm{~Sv}$.

The Irminger Current (IC) flows northeastwards along the western flank of the Reykjanes Ridge. In 2014, its topto-bottom integrated transport amounted to $17.5 \pm 7.3 \mathrm{~Sv}$, which accounts for both the northward and the southward currents east of the IG. Considering only the northward velocities brings the IC intensity to a value of $22.7 \pm 6.5 \mathrm{~Sv}$.

The Eastern Reykjanes Ridge Current (ERRC) flows southwestward east of the Reykjanes Ridge. In 2014, its topto-bottom integrated transport between the Reykjanes Ridge and station 34 (Fig. 3) amounted to $13.6 \pm 6.0 \mathrm{~Sv}$ southward.

The North Atlantic Current (NAC) at the OVIDE section consists of meandering branches flowing northeastward between the center of the Iceland Basin and the Azores-Biscay Rise (D2016). To determine its horizontal extension, we 


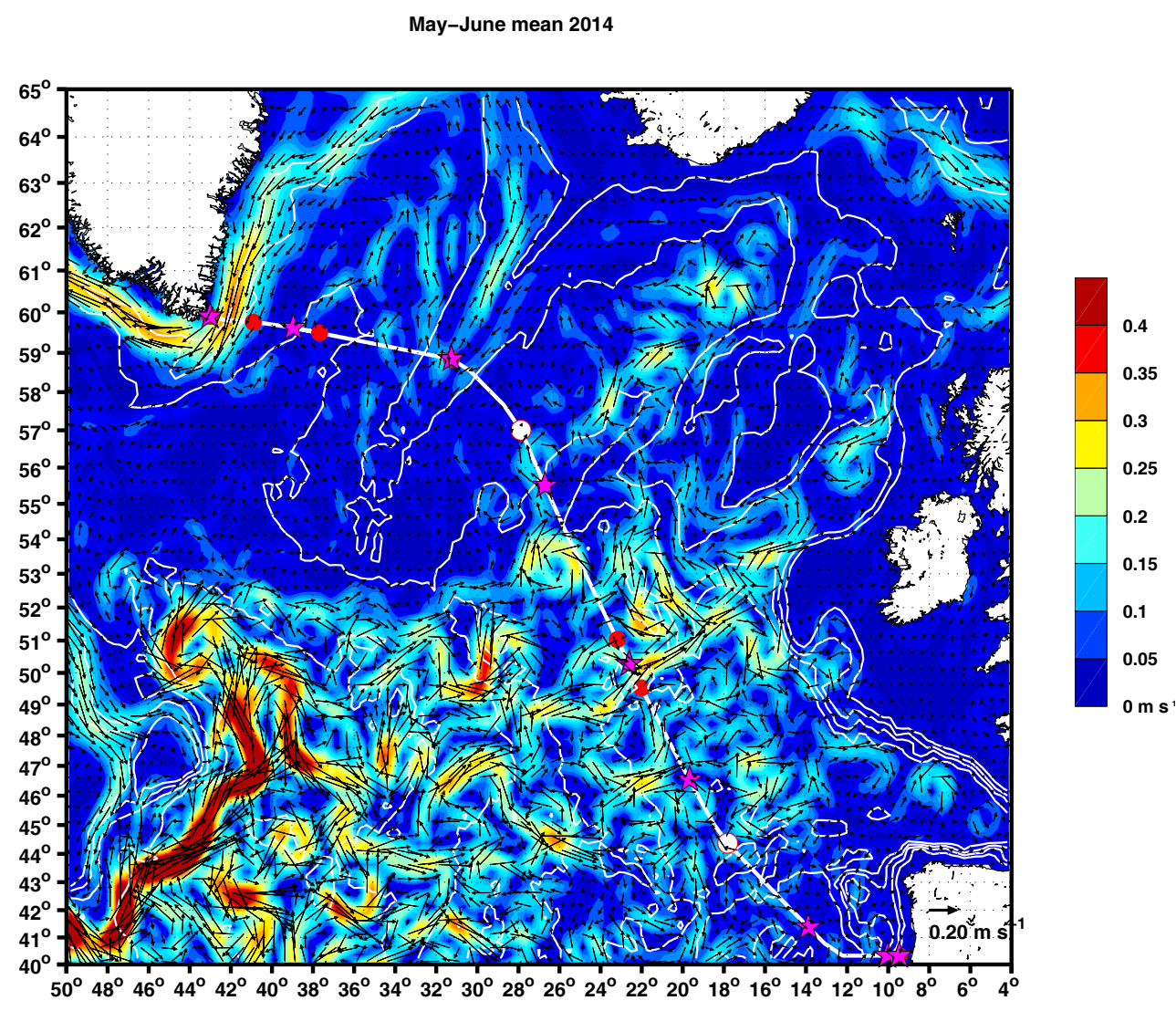

Figure 5. Surface velocities $\left(\mathrm{m} \mathrm{s}^{-1}\right)$ derived from AVISO data: arrows indicate current direction and colors indicate current intensity. The white line represents the OVIDE section. The red and white points indicate the extension of the different dynamical structures crossing the OVIDE section in 2014. The white points delimit the extension of the NAC. The pink stars indicate the position of the GEOVIDE super stations and XL stations. The bathymetry contours every $1000 \mathrm{~m}$ are indicated by light white lines.

used the top-to-bottom volume transport accumulated from Greenland to each GEOVIDE station (the barotropic stream function; Fig. 4) and the AVISO altimetry data (Fig. 5; http: //www.aviso.altimetry.fr/en/my-aviso.html). The NAC intensity was quantified as the accumulated transport from the relative minimum of the barotropic stream function in the central Iceland Basin up to the maximum of the barotropic stream function in the Western European Basin (D2016). In the Iceland Basin, we found two relative minima of the stream function (Fig. 4) due to the presence of an anticyclonic eddy, which was considered as part of the NAC as justified in the next section. The limits of the NAC along the OVIDE section are indicated by white circles in Fig. 5, between which the different branches of the NAC appear as energetic northeastward currents. The top-to-bottom intensity of the NAC in 2014 amounted to $32.2 \pm 11.4 \mathrm{~Sv}$. Following D2016, three different branches of the NAC can be differentiated: the northern branch (NNAC), the Subarctic Front (SAF), and the southern branch (SNAC). The SAF is identified as the concomitant intense northward transport and salinity increase around $22.5^{\circ} \mathrm{W}$ (Fig. 4). In 2014, the top-to-bottom transport of the different NAC branches was
$-0.1 \pm 6.4,25.0 \pm 3.0$, and 7.3 $\pm 4.9 \mathrm{~Sv}$, respectively. Note that the net transport in the northern branch is quasi null with a large associated error; by contrast, the SAF bears a very intense central branch. This point is discussed in Sect. 4.

The easternmost dynamical feature of the OVIDE section is the NAC recirculation. Its intensity of $10.1 \pm 6.4 \mathrm{~Sv}$ southwestward is determined as the top-to-bottom accumulated transport between the southern limit of the NAC and the easternmost station of the OVIDE section.

The intensity of the AMOC across the OVIDE section, referred as MOC hereafter, was defined from the velocities given by the inverse model as the maximum of the surfaceto-bottom integrated stream function computed in vertical coordinates of potential density referenced to $1000 \mathrm{~m}\left(\sigma_{1}\right)$. During the GEOVIDE cruise, it amounted to $18.7 \pm 2.7 \mathrm{~Sv}$ and was found at $\sigma_{1}=32.15 \mathrm{~kg} \mathrm{~m}^{-3}$. Additionally, using the independent monthly MOC index created by Mercier et al. (2015), which is based on altimetry and Argo data, the intensity of the MOC across the OVIDE section amounted to the compatible value of $21.3 \pm 1.5 \mathrm{~Sv}$ in June 2014 , while the 2014 annual mean value of the MOC index was $18.2 \mathrm{~Sv}$. 
Heat transport during the GEOVIDE cruise was estimated at $0.56 \pm 0.06 \mathrm{PW}$. Following the Bryden and Imawaki (2001) methodology adapted by Mercier et al. (2015) in isopycnal coordinates (see their Eq. 1), we found $0.50 \mathrm{PW}$ transported by the overturning circulation, $0.04 \mathrm{PW}$ by the horizontal or gyre circulation, and $0.02 \mathrm{PW}$ by the net transport across the section.

\subsection{Fronts and eddies}

Together with the above-mentioned permanent circulation features, we observed some remarkable eddies during the GEOVIDE cruise that could modify the "typical" patterns of properties defined by D2016 or García-Ibáñez et al. (2015), and they can affect the distribution of tracers measured during the GEOVIDE cruise.

The identification of eddies and fronts was based on the analysis of surface velocities provided by AVISO (see Fig. 5), the velocity profiles given by both the S-ADCP and the inverse model (Fig. 3), and the vertical distribution of properties (Fig. 2). In Fig. 5, we clearly identify the most energetic currents crossing the OVIDE section as the WBC close to Greenland and the NAC with its different branches. Moreover, all the energetic eddies intersecting the OVIDE section were observed in the NAC (Fig. 6) and identified in Fig. 3. From north to south, the first eddy intersecting the section, referred to as the northern eddy, is detected at $56.5^{\circ} \mathrm{N}$, $27^{\circ} \mathrm{W}$ (Fig. 5). This eddy lies between stations 34 and 32 (Figs. 3, 6), extending from the surface to the bottom but intensified in the upper $600 \mathrm{~m}$. From Fig. 6, we inferred that this eddy was generated in April at approximately $56.5^{\circ} \mathrm{N}$, $26^{\circ} \mathrm{W}$ from the meandering of the NAC north of the OVIDE section; its position is marked by yellow squares in Fig. 6. In May 2014, the eddy was totally formed and intersected the section between 55.5 and $57^{\circ} \mathrm{N}$. In June 2014, the eddy moved southwestward, in agreement with the general displacement of anticyclonic eddies in the SPNA. The core of the northern eddy, between stations 34 and 32 in Fig. 2a and $\mathrm{b}$, shows properties warmer and saltier than the surrounding water, confirming the NAC origin of this eddy; this is why this anticyclonic eddy has been considered as part of the northern branch of the NAC. Note that in May-June, the net transport of this eddy from the surface to the bottom is almost $0 \mathrm{~Sv}$ (see Fig. 4 between stations 34 and 32).

A large anticyclonic eddy, the central eddy, is observed at $53^{\circ} \mathrm{N}, 26^{\circ} \mathrm{W}$ at a tangent to the OVIDE section between stations 30 and 29 (red squares in Fig. 6). However, no signal was detected in the barotropic stream function (Fig. 4) since the northward and southward velocities (Fig. 3a) compensated once integrated between the two stations (Fig. 3b). It is noteworthy that, contrary to the previous anticyclonic eddy, this one is stationary south of the OVIDE section between March and June (Fig. 6) and was found to be quasi-permanent in the altimetry data since 1993 (figure not shown). Hydrographic properties measured at stations 29 and
30 showed cold and fresh water between 350 and $500 \mathrm{~m}$ of depth, typical of the Subarctic Intermediate Water (SAIW), which is most likely trapped by this anticyclonic eddy.

The most remarkable front present on the OVIDE section is the SAF, associated with the central branch of the NAC. Along the OVIDE section, it is situated between 49.5 and $51^{\circ} \mathrm{N}$ latitude and 23.5 and $22^{\circ} \mathrm{W}$ longitude (red points in Figs. 5 and 6). This front separates cold and fresh water of subpolar origin from warm and salty water of subtropical origin; it is identifiable in Fig. 2 at station 26 by the steep slope of the isotherms and isohalines. The position of this front is known to vary spatially (Bersch 2002; Bower and Von Appen, 2008; Lherminier et al., 2010), creating anomalies of salinity and temperature that will be discussed later.

Finally, also in Fig. 5, we identified the southern branch of the NAC with a maximum in the eastward velocities found at $46.5^{\circ} \mathrm{N}, 22^{\circ} \mathrm{W}$ west of GEOVIDE super station 21 . Despite very rich mesoscale activity, we can distinguish in Fig. 5 that the southern NAC splits into two subbranches before crossing the OVIDE section, in agreement with D2016. The northernmost subbranch cuts the section between stations 23 and 24 at $48.5^{\circ} \mathrm{N}, 21^{\circ} \mathrm{W}$. The southernmost subbranch evolves into a cyclonic eddy (the southern cyclonic eddy; light green square in Fig. 6) that intersects the OVIDE section south of station 21 . This eddy is also observed in the velocity profiles (Fig. 3) between stations 21 and 19, as well as by the uplifting of isotherms and isohalines in Fig. 2. To its southeast, an anticyclonic eddy (orange square in Fig. 6) centered on station 18 marks the southern limit of the NAC and the beginning of the southwestward recirculation. On the OVIDE section, the southern anticyclonic eddy also marks the northwest limit of the presence of Mediterranean Water at about $1000 \mathrm{~m}$ of depth (Fig. 2b), which is consistent with its slow westward advection since March (Fig. 6). Note that while the southern anticyclonic eddy (orange square in Fig. 6) looks stable over time, the southern cyclonic eddy (light green square in Fig. 6) seems more transitory since it is not clearly visible in April.

\subsection{Thermohaline anomalies in $\mathbf{2 0 1 4}$}

The anomalies of potential temperature $(\theta)$, salinity $(S)$, and dissolved oxygen along the OVIDE section in 2014 were computed on pressure levels (Fig. 7) with respect to the average of the six repetitions of the OVIDE section (summers 2002, 2004, 2006, 2008, 2010, and 2012). Only anomalies larger than 1 standard deviation from the mean are represented in Fig. 7. In the following, $S$ and $\theta$ anomalies were quantified as the mean values of the anomaly patches represented in Fig. 7. We identified four different types of anomalies along the OVIDE section. First, negative anomalies in surface intermediate waters were observed above the WMLD over the Reykjanes Ridge (in the IC and the ERRC) and east of $20^{\circ} \mathrm{W}$ (in the SNAC and its recirculation). In the former, the $S$ and $\theta$ anomalies were quantified at -0.08 and 

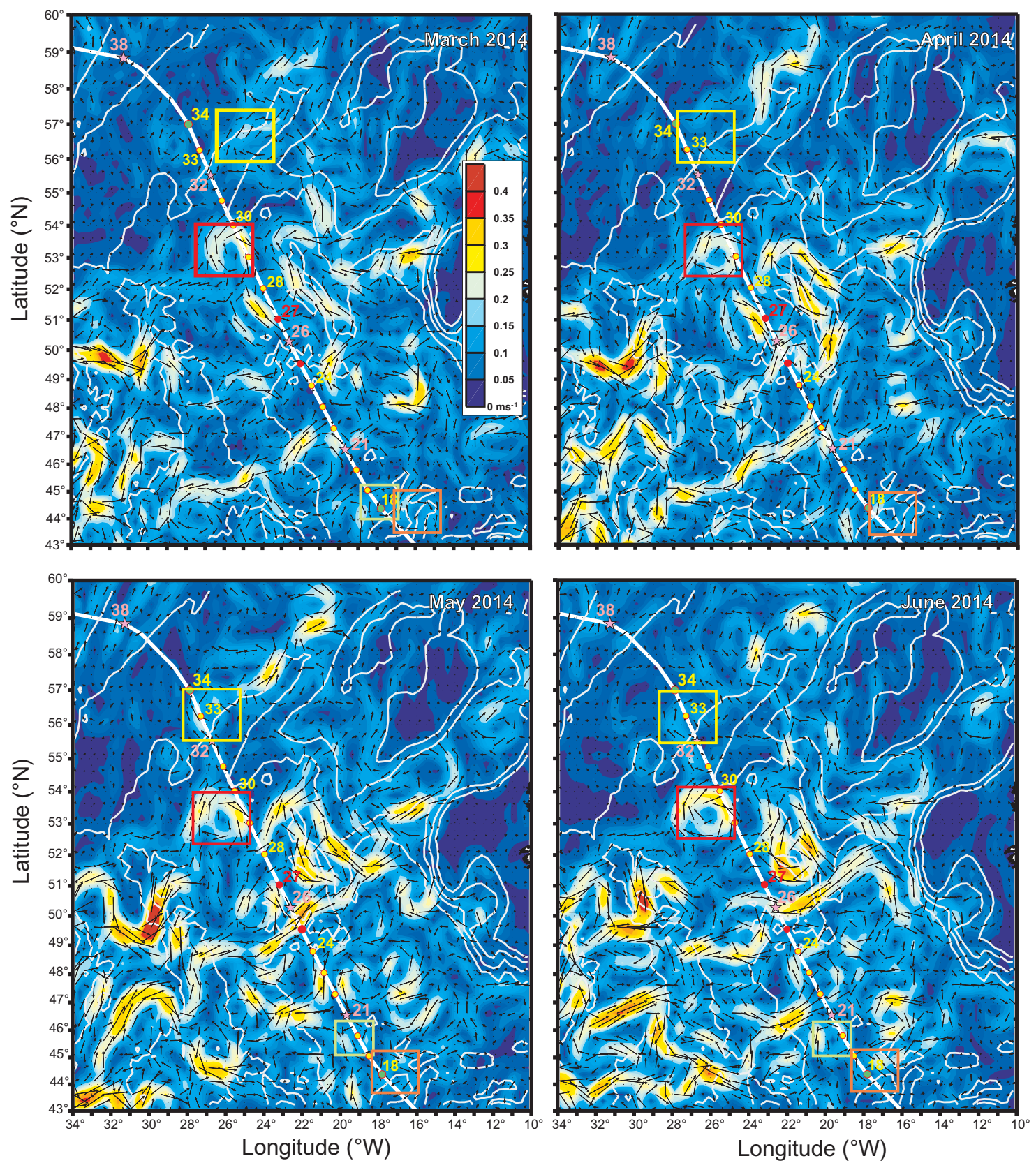

Figure 6. Surface velocities derived from AVISO data, as in Fig. 5 but zooming in on the NAC region in March, April, May, and June 2014. The yellow, red, clear green, and orange squares indicate the position of the northern, central, southern cyclonic, and southern anticyclonic eddies, respectively, discussed in Sect. 3.2. The numbers of the GEOVIDE stations are indicated in all the plots: pink for the super stations and XL stations and yellow for regular stations. The red and green points delimit the position of the SAF and the NAC, respectively, during the period of the GEOVIDE cruise. The bathymetry contours every $1000 \mathrm{~m}$ are indicated by light white lines.

$-1.04{ }^{\circ} \mathrm{C}$, respectively. In the latter, the negative anomalies of $S$ and $\theta$ amounted to -0.11 and $-0.70^{\circ} \mathrm{C}$. In the ERRC, negative $S$ and $\theta$ anomalies also appeared below the WMLD amounting to -0.06 and $-0.80^{\circ} \mathrm{C}$, respectively. It concerns a water mass that is different from the one in the WMLD; both water masses are separated by a negative anomaly of oxygen (Fig. 2c) and a maximum of potential vorticity (not shown). The cooling and freshening of the surface intermediate waters were not compensated for in density: the cooling dominated and the water was significantly denser (figure not shown). Concurrently, a positive oxygen anomaly was observed.

In both the Irminger Sea and the Iceland Basin, positive anomalies of $S$ and $\theta$ were observed in waters deeper than 

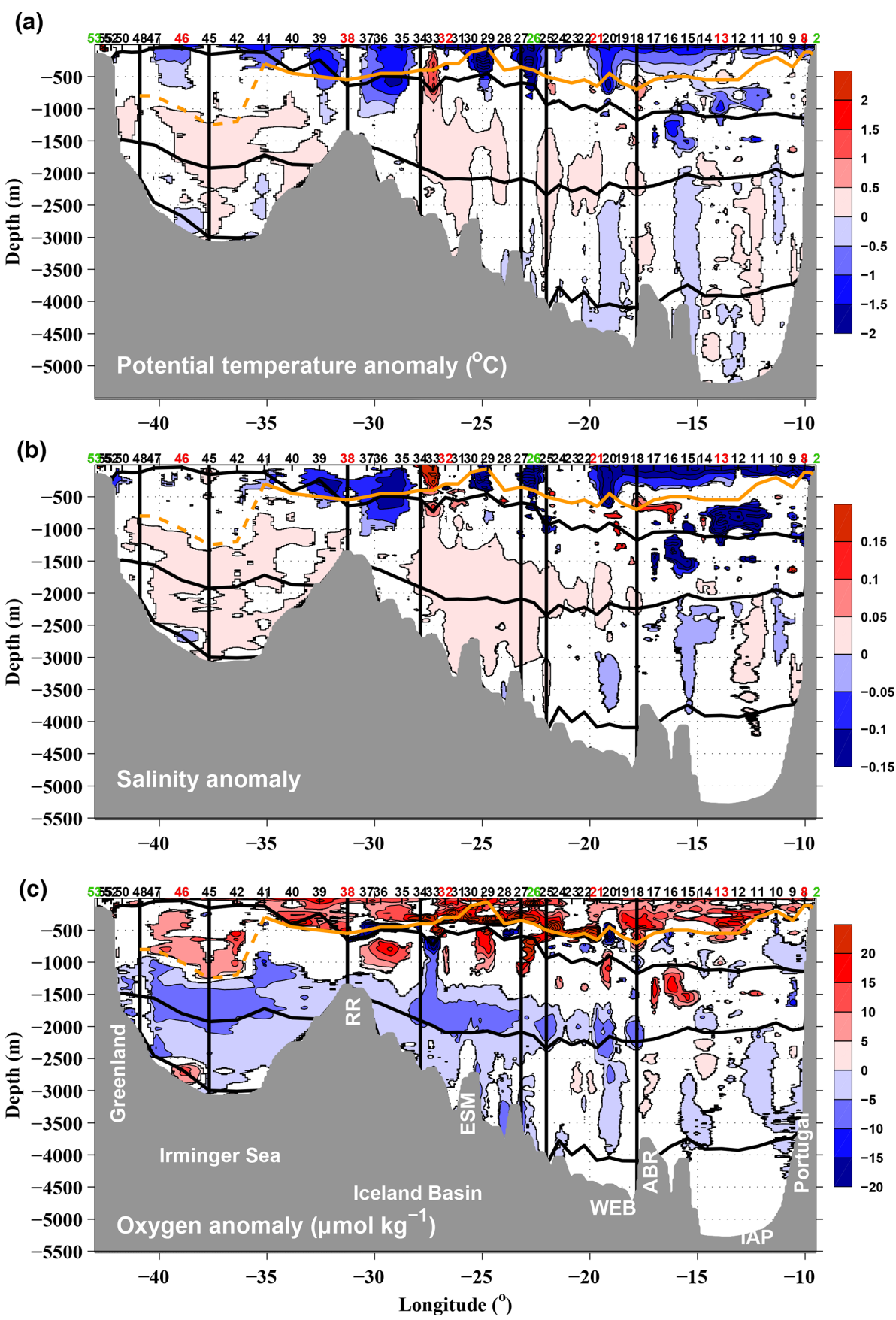

Figure 7. Anomalies of potential temperature $\left(\mathbf{a}\right.$; in $\left.{ }^{\circ} \mathrm{C}\right)$, salinity $(\mathbf{b})$, and oxygen $\left(\mathbf{c}\right.$; in $\left.\mu \mathrm{mol} \mathrm{kg}{ }^{-1}\right)$ in 2014 with respect to the OVIDE 2002-2012 mean. Only anomalies larger than 1 standard deviation of the 2002-2012 values are colored in the figure. Station numbers follow the color code of Fig. 2. The orange line indicates the winter mixed layer depth (WMLD); in the Irminger Sea, the dotted line indicates the WMLD that was not formed locally (see Sect. 4.2). The acronyms in panel (c) are as in Figs. 2 and 3.

$1000 \mathrm{~m}$. In the Irminger Sea, the $S$ and $\theta$ anomalies amounted to 0.017 and $0.122^{\circ} \mathrm{C}$, respectively. In the Iceland Basin, they reached similar values, i.e., 0.014 and $0.125^{\circ} \mathrm{C}$. In both basins, these anomalies coincided with significant negative oxygen anomalies up to $-20 \mu \mathrm{mol} \mathrm{kg}{ }^{-1}$, suggesting that this water mass was not recently ventilated.
In the Iberian Abyssal Plain (IAP), negative anomalies of $S(-0.12)$ and $\theta\left(-0.67^{\circ} \mathrm{C}\right)$ were observed at the level of the Mediterranean Water (MW) above and below the isopycnal $32.15 \mathrm{~kg} \mathrm{~m}^{-3}$. Although remarkable, those anomalies are difficult to interpret because of the high variability of the Meddy distribution in this area. 
The displacement of fronts or eddies already identified in the previous section generated other occasional anomalies. The salty and warm anomaly found at $27.4^{\circ} \mathrm{W}$ above isopycnal $32.15 \mathrm{~kg} \mathrm{~m}^{-3}$ is explained by the anticyclonic eddy (the northern eddy), which advected water from the NAC. The fresh and cold anomaly localized at $25^{\circ} \mathrm{W}$ is a consequence of the SAIW brought by the anticyclonic eddy (the central eddy) located at $53^{\circ} \mathrm{N}, 26^{\circ} \mathrm{W}$ and touching the OVIDE section between stations 30 and 29. Finally, the southeastward displacement of the SAF created a fresh and cold anomaly between $23^{\circ} \mathrm{W}$ and $22^{\circ} \mathrm{W}$ because the warm and salty North Atlantic Central Water (NACW) usually found in this area was replaced by subpolar water.

In Fig. 7c, we found an increase in the ventilation in the first $1000 \mathrm{~m}$, while the deeper waters are less oxygenated when compared to the 2002-2012 period. The anticorrelation between the oxygen anomalies and the $\theta-S$ anomalies will be discussed in Sect. 4.2.

\subsection{Settling the special GEOVIDE stations in the framework of the large-scale and mesoscale circulation}

As part of the GEOTRACES program, seven super stations and three XL stations were established along the OVIDE section in 2014 for sampling TEIs in the SPNA. The TEI results are published in this Biogeosciences GEOVIDE Special Issue (e.g., Cossa et al., 2017, about mercury; Lemaître et al., 2017, about particulate barium; Le Roy et al., 2017, about radium 226; Tonnard et al., 2017, about dissolved iron). In order to facilitate the interpretation of the TEI distribution, here we contextualize the super stations and XL stations (red and green numbers, respectively, in Figs. 2, 3, and 4 and pink stars in Fig. 5) in the physical framework described above. Apart from station 26, which was specifically selected in real time in the middle of the SAF, and station 38 over the Reykjanes Ridge, all the other special stations are representative of relatively large hydrographic domains since they are not strongly affected by the peculiar mesoscale features described in Sect. 3.2.

Specifically, from Greenland to Portugal, these stations were located in the East Greenland Coastal Current (EGCC, station 53), the East Greenland-Irminger Current (EGIC, station 60, same position as 51), the Irminger Gyre (station 44, same position as station 46), in the middle of the Iceland Basin (part of the NNAC, station 32), in the SNAC (station 21), in the center of the southward recirculation in the IAP (station 13), on the Iberian Peninsula slope (station 8), and on the Portuguese continental shelf (station 2). Importantly for the GEOTRACES community, although the super stations and XL stations are representative in terms of circulation, the large-scale $S-\theta$ anomalies detailed in Sect. 3.4 need to be taken into account when comparing GEOVIDE data with data from the previous decade.

\section{Discussion}

\subsection{State of the circulation during the GEOVIDE cruise with respect to the mean state}

We will first discuss the circulation patterns seen during the GEOVIDE cruise in comparison with the mean position, extension, and intensity of the main currents intersecting the OVIDE section defined by D2016. Despite the coarse resolution of the GEOVIDE stations, all the circulation structures are identified in the inverse model solution (Table 1). The intensity of the WBC and the IG are similar to the mean state with a quite high reliability (low relative error). The transports of the ERRC and the southwestward recirculation in the IAP are also very similar to the mean state, but remained to a large degree uncertain. Conversely, the IC and NAC are different from the mean state, but not significantly.

When defining the IC as in D2016, we saw an increase in the IC intensity in 2014, but within the observed variability (Table 1). However, the such-defined IC encompasses a warm and salty northward transport and a cold and fresh southward transport. So, to go further in the analysis of IC, we compared its northward component near Reykjanes Ridge with its equivalent from the 2002-2012 mean data (not shown in D2016). In this case, the IC amounted to $22.7 \pm 6.5 \mathrm{~Sv}$, which is significantly larger than the northward IC computed from D2016 data: $11.0 \pm 3.4$ Sv. Our result is similar to the estimate of Väge et al. (2011) who quantified the IC at 19 $\pm 3 \mathrm{~Sv}$ (1991-2008). Therefore, we conclude that the thus-defined IC was strengthened in 2014 with respect to the 2002-2012 mean value. Note that the northward component of the IC between stations 38 and 41 transports water masses that are warmer and saltier than those advected southward between stations 41 and 45, (Fig. 2); so, the intensification of the Irminger Current is meaningful in terms of the transport of warm and salty water to the north and actually contributes to the upper limb of the MOC (Fig. 4, dotted line).

Concerning the NAC, its 2014 intensity of $32.2 \pm 11.4 \mathrm{~Sv}$ is weaker although within the limits of the observed variability $(41.8 \pm 3.7 \mathrm{~Sv})$. Through the decomposition of this wide current, it is very likely that the difference comes from the change in the intensity of the northern branch of the NAC: $-0.1 \pm 6.4 \mathrm{~Sv}$ was computed in GEOVIDE, while $11.0 \pm 3.0 \mathrm{~Sv}$ was estimated by D2016. However, the weakening of the northern branch of the NAC in 2014 was partially compensated for by the doubling of transport of the NAC central branch when compared with the 2002-2012 mean $(25 \pm 3 \mathrm{~Sv}$ vs. $14 \pm 6 \mathrm{~Sv})$, suggesting that there was a partial transfer of transport from the northern to the central branch of the NAC.

The SAF, that bears the central branch of the NAC, also shows a remarkable southeastward displacement of about $100 \mathrm{~km}$ in 2014 with respect to the mean circulation pattern (station 26 in Fig. 1). A careful study of the ADT stream- 


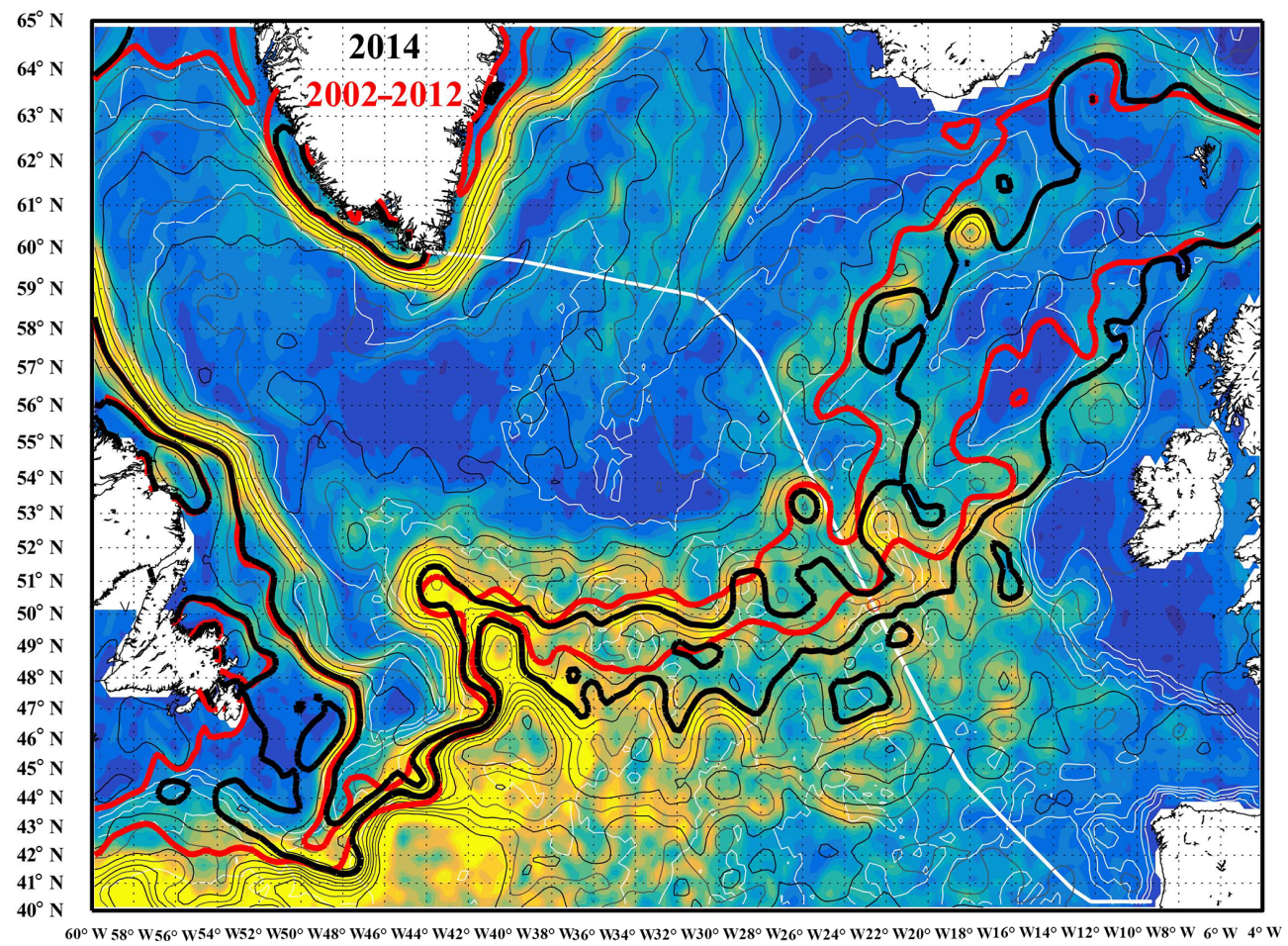

Figure 8. Contours of the absolute dynamic topography (ADT) averaged over 2014 (in thin lines); contours are every $0.05 \mathrm{~m}$. Thick contours correspond to the levels encompassing the SAF during OVIDE cruises: red for the mean 2002-2012 and black for 2014. Note that the temporal trend in the mean ADT over the whole box $\left(2.8 \mathrm{~mm} \mathrm{yr}^{-1}\right)$ was removed. Bathymetry (1000 $\mathrm{m}$ step contours) and the OVIDE section are plotted in white. Colors represent the absolute velocity of the current (yellow for velocities stronger than $0.3 \mathrm{~m} \mathrm{~s}^{-1}$ ).

Table 1. Intensity (top-to-bottom integrated) of the different dynamical structures defined in Sect. 3.1 for 2014 and the mean values (20022012) estimated by Daniault et al. (2016). Note that the errors given for the GEOVIDE estimates come from the covariance matrix resulting from the inverse model. Otherwise, the errors given with the mean values are the standard deviation of the six estimates of each current.

\begin{tabular}{|c|c|c|c|c|c|c|c|}
\hline \multirow[t]{2}{*}{ Units: Sv } & \multirow[t]{2}{*}{ WBC } & \multirow[t]{2}{*}{ IG } & \multicolumn{2}{|c|}{ IC } & \multirow[t]{2}{*}{ ERRC } & \multirow[t]{2}{*}{ NAC } & \multirow[t]{2}{*}{ Recirculation } \\
\hline & & & as D2016 & $\begin{array}{l}\text { Northward } \\
\text { transport }\end{array}$ & & & \\
\hline GEOVIDE & $-30.3 \pm 2.1$ & $6.8 \pm 3.0$ & $17.5 \pm 7.3$ & $22.7 \pm 6.5$ & $-13.6 \pm 6.0$ & $32.2 \pm 11.4$ & $-10.2 \pm 6.4$ \\
\hline MEAN (2002-2012) & $-33.1 \pm 2.6$ & $7.7 \pm 2.1$ & $9.5 \pm 3.4$ & $11.0 \pm 3.4$ & $-12.1 \pm 1.1$ & $41.8 \pm 3.7$ & $-13.0 \pm 2.0$ \\
\hline
\end{tabular}

lines (Fig. 8) showed that this displacement was not due to a peculiar meandering of the front and that the SAF was actually narrower and located more to the southeast in 2014 when compared to the 2002-2012 mean. Bersch et al. (2007) linked the northwestward displacement of the SAF in the eastern North Atlantic in the late 1990s to a shift from positive to negative values in the index of the North Atlantic Oscillation (NAO), which is the dominant mode of atmospheric variability over the North Atlantic. After a decade of neutral values, the winter NAO index turned positive in 2011 and continued positive in 2013 and 2014 (Hurrell et al., 2017). The southeastward displacement of the SAF is thus symmetric to Bersch et al. (2007) and consistent with their observations.
Along the OVIDE section, some permanent circulation features were observed by D2016 because the velocity was found to be in the same direction for all repeated measures over the 2002-2012 period (see their Fig. 4). In our Fig. 3, we found most of these permanent circulation features: the WBC, IC, ERRC, two deep southward veins transporting the Iceland-Scotland Overflow Water (ISOW) in the Iceland Basin, and the northward transport over Eriador Seamount in the intermediate layer. Only the "permanent" anticyclonic eddy marking the southern limit of the NAC moved: it was expected between stations 20 and 21 according to the mean circulation (Fig. 1), but was instead found at station 18, i.e., more to the southeast, during the GEOVIDE cruise (and previously called the southern anticyclonic eddy). 


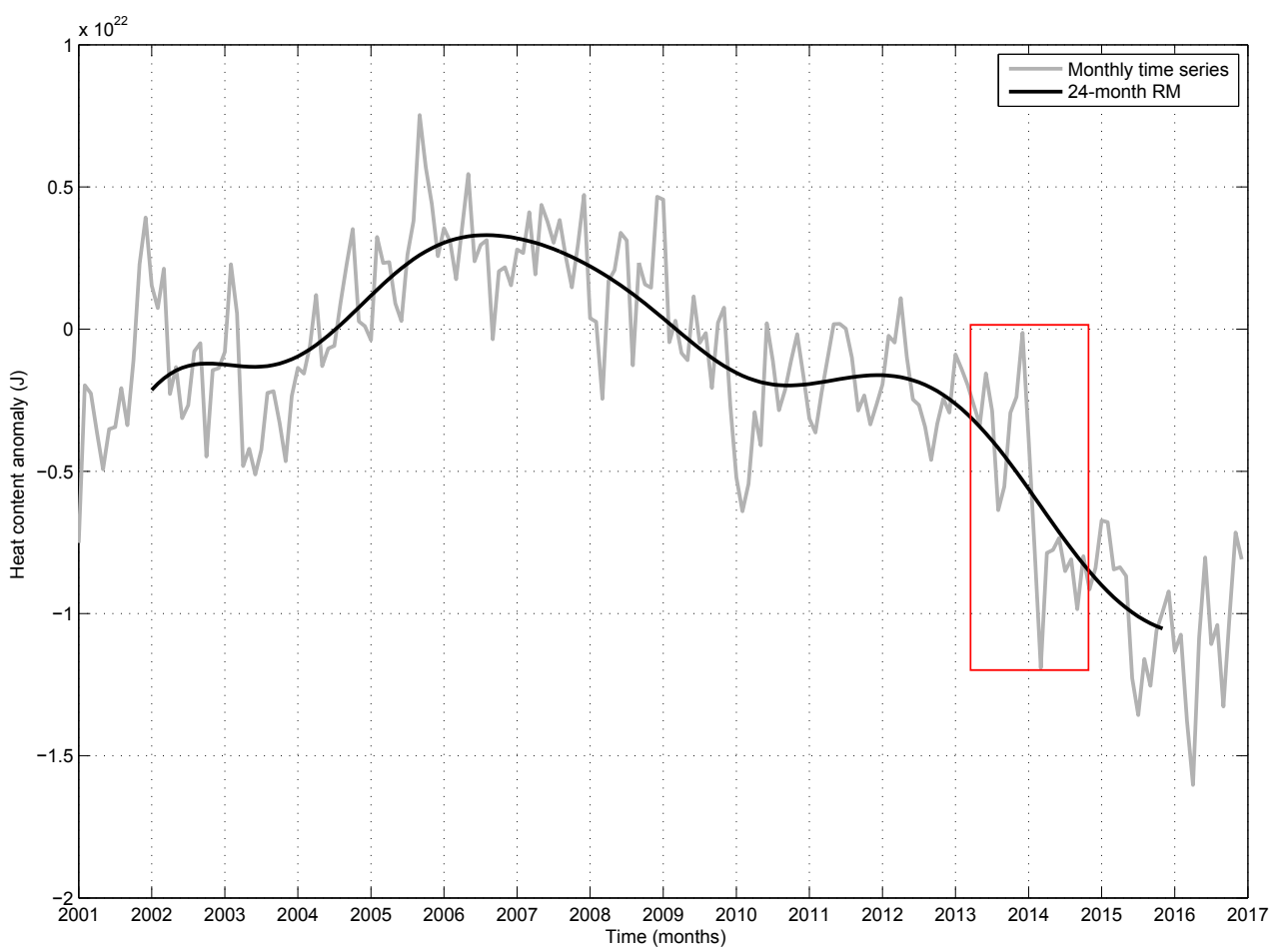

Figure 9. Heat content anomalies with respect to the mean heat content for the period 2002-2012 in the upper $1000 \mathrm{~m}$ of the region $40-60^{\circ} \mathrm{N}$, $45-10^{\circ} \mathrm{W}$ : the monthly time series in gray and the 2-year running mean in black. Data source: EN4 database (Good et al., 2013). The red square highlights the short-term cooling event analyzed in this paper.

(a)

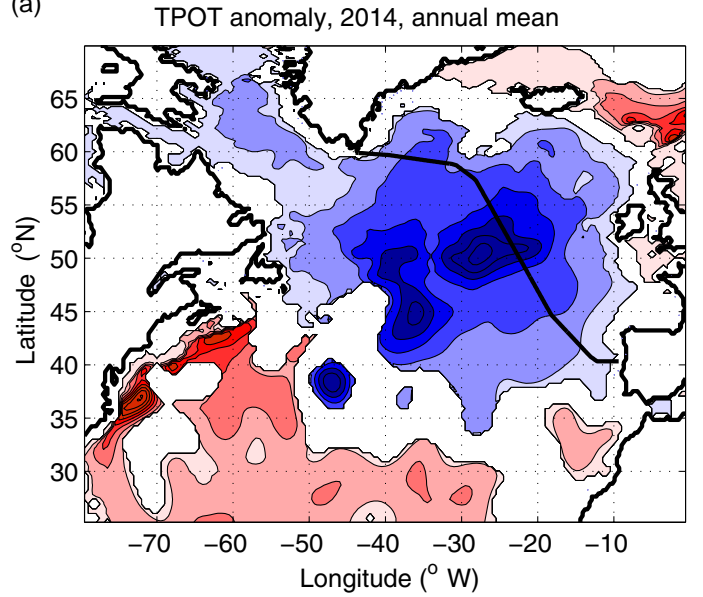

(b)

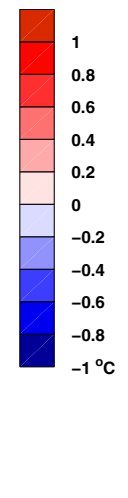

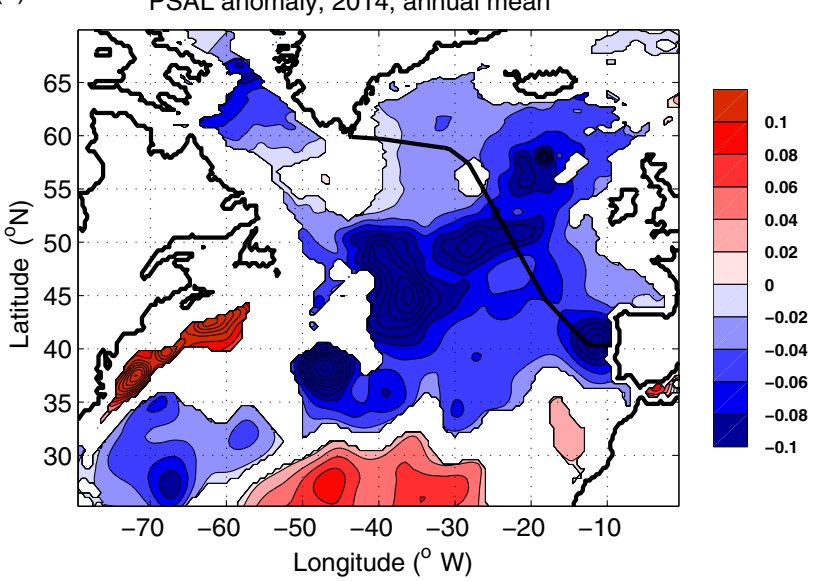

Figure 10. Annual mean anomalies of potential temperature (a) and salinity (b) in the surface waters (20-500 m) in the North Atlantic estimated from the ISAS database. The reference period for estimating the anomalies was 2002-2012. The OVIDE section is represented by a black line. Only anomalies larger than 1 standard deviation are colored in the figure.

The inverse model solution also provides a robust estimate of both the intensity of the MOC and the heat transport. We observed a heat transport of $0.56 \pm 0.06 \mathrm{PW}$. To compare it with the 2002-2010 average, we used the data of Mercier et al. (2015), without data from 1997 because it did not belong to our reference period, and obtained $0.47 \pm 0.05 \mathrm{PW}$. Even if the 2014 value is not statistically different from the mean, it is surprising to find such a high heat transport considering the cold anomaly observed in the NAC surface waters (Fig. 7). To determine the role of the MOC in this result, we first looked at the 2014 MOC $(18.7 \pm 2.7 \mathrm{~Sv})$, which is $2.5 \mathrm{~Sv}$ higher than the 2002-2010 average $(16.2 \pm 2.4 \mathrm{~Sv})$. 


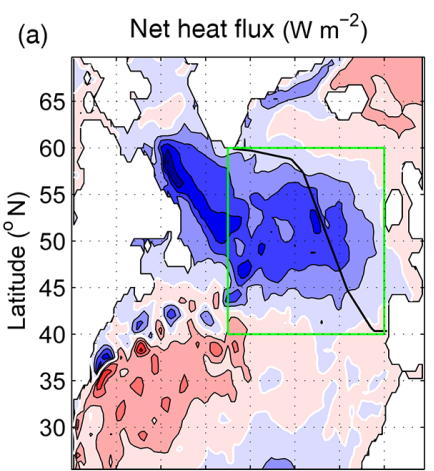

$80 \quad 70 \quad 60 \quad 50 \quad 40 \quad 30 \quad 20 \quad 10$

Net freshwater gain $\left(10^{-4} \mathrm{~m}\right),=$ prec + evap $(\mathrm{e})$

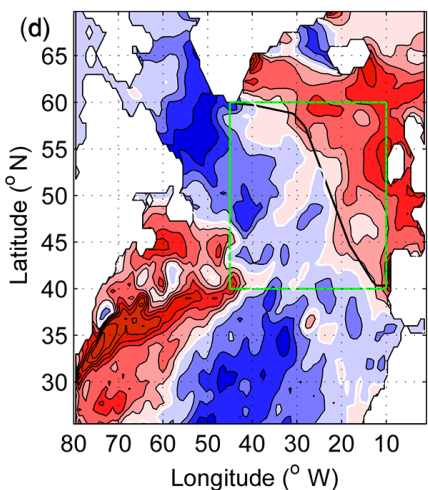

(b) Sensible heat flux $\left(\mathrm{W} \mathrm{m}^{-2}\right)$

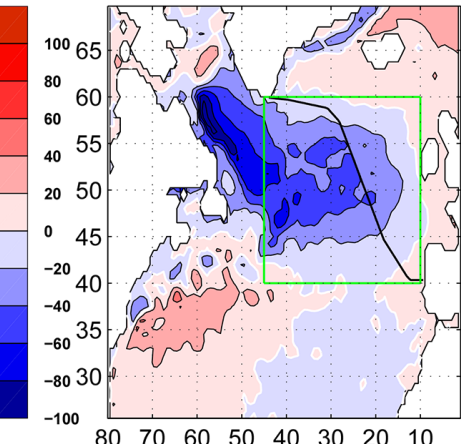

Evaporation $\left(10^{-4} \mathrm{~m}\right)$

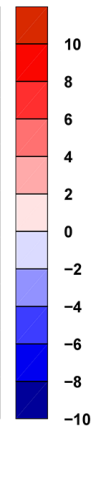

(e)

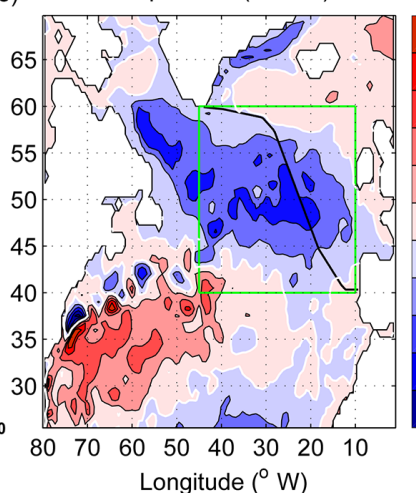

(c) Latent heat flux $\left(\mathrm{W} \mathrm{m}^{-2}\right)$

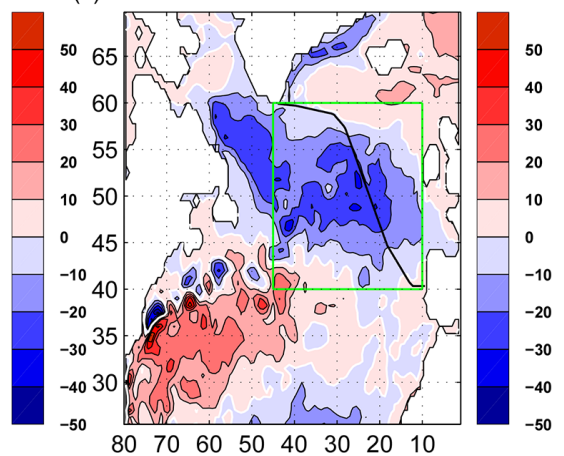

(f) Precipitation $\left(10^{-4} \mathrm{~m}\right)$

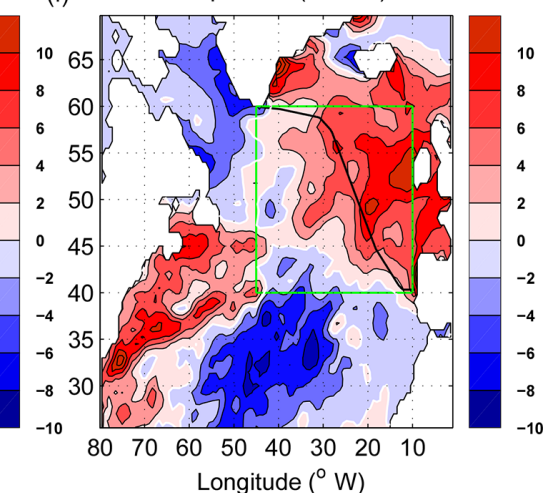

Figure 11. The 2014 winter-spring (DJFMAM) mean anomalies. The anomalies were calculated with respect to the period 2002-2012. Panels (a), (b), and (c) are the total heat, sensible heat, and latent heat air-sea flux, respectively, in $\mathrm{W} \mathrm{m}^{-2}$; positive or negative values indicate ocean heat gained or lost. Panels (d), (e), and (f) are net gain of freshwater, evaporation, and precipitation; the unit is $10^{-4} \mathrm{~m}$; positive or negative values indicate ocean freshwater gain or loss. The contours of anomalies $0 \mathrm{~W} \mathrm{~m}^{-2}$ (in $\mathbf{a}, \mathbf{b}$, and $\mathbf{c}$ ) and of $0 \mathrm{~m}$ (in $\mathbf{d}, \mathbf{e}$, and f) are represented by a white line. Data source: ERA-Interim. The green square represents the area for which the changes in heat and freshwater content and the integrated air-sea heat and freshwater flux represented in Fig. 12 were evaluated.

Note that including 2012 data (15 Sv and 0.39 PW; not published) in the mean increases the difference with 2014. This result is in line with the observation of Rossby et al. (2017), who found that the MOC intensity at $59.5^{\circ} \mathrm{N}$ was larger for the period from late 2012 to early 2016 than the average over 1993-2016. To improve our quantification of the influence of the MOC on heat transport, we used the heat transport proxy

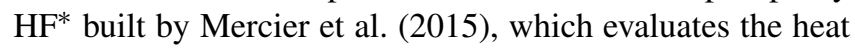
transport only driven by the diapycnal circulation known to be the dominant term of heat transport for all the OVIDE cruises. The proxy (Eq. 3) is based on the MOC intensity $\left(\mathrm{MOC}_{\sigma}\right)$ and the temperature difference between the upper and lower limbs of the MOC $(\Delta T)$ :

$\mathrm{HT}^{*}=\rho \cdot c_{\mathrm{p}} \cdot \Delta T \cdot \mathrm{MOC}_{\sigma}$,

where $\mathrm{HT}^{*}, \rho$, and $c_{\mathrm{p}}$ are the heat transport proxy, the in situ density, and the specific heat capacity, respectively. During GEOVIDE, HT* amounted to $0.49 \mathrm{PW}$, with $\mathrm{MOC}_{\sigma}=18.7 \mathrm{~Sv}$ and $\Delta T=6.40^{\circ} \mathrm{C}$. The 2002-2010 mean values of $\mathrm{HT}^{*}, \mathrm{MOC}_{\sigma}$, and $\Delta T$ were $0.43 \mathrm{PW}, 16.2 \mathrm{~Sv}$, and $6.79^{\circ} \mathrm{C}$, respectively. So, the heat transport index and $\mathrm{MOC}_{\sigma}$ were larger in 2014 than the mean values, while the $\Delta T$ was smaller, which is consistent with the cold anomaly. These results show that the larger $\mathrm{MOC}_{\sigma}$ measured during GEOVIDE was enough to compensate for the heat transport decrease due to the cooling of the surface waters. This result might be the effect of short-term variability since it contrasts with the study of Desbruyères et al. (2015), who argued that the longterm variability of the ocean heat transport at the OVIDE section is dominated by the advection by the mean velocity field of temperature anomalies formed upstream rather than the velocity anomalies acting on temperature.

\subsection{Negative anomalies of $\theta$ and $S$ in surface intermediate layers explained by the local atmospheric forcing}

The long-term evolution of heat content anomaly with respect to the 2002-2012 mean (Fig. 9) was calculated in the upper $1000 \mathrm{~m}$ over the SPNA region delimited by $40-60^{\circ} \mathrm{N}$ latitude and $45-10^{\circ} \mathrm{W}$ longitude (green square in Fig. 11). As shown by Robson et al. (2016), the SPNA started a new long-term cooling period since the mid-2000s. By analyzing the outputs of coupled climate models, Robson et al. (2017) 


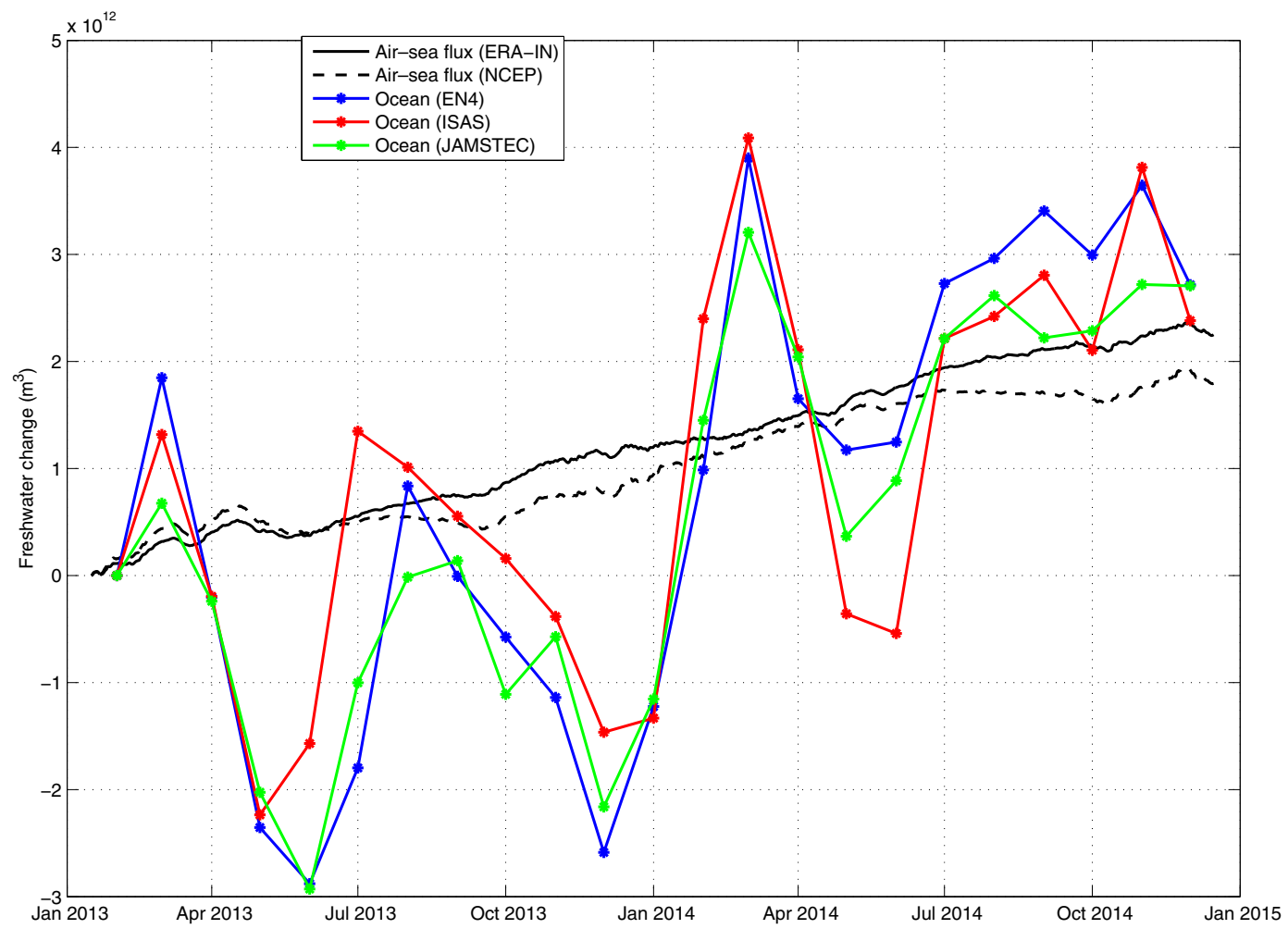

Figure 12. Monthly time series of the freshwater content change between one month and the month before (in $\mathrm{m}^{3}$ ) accumulated since 1 February 2013 in the upper $1000 \mathrm{~m}$ of the box delimited by $40-60^{\circ} \mathrm{N}$ and $45-10^{\circ} \mathrm{W}$ computed from three datasets: EN4 (blue), ISAS (red), and JAMSTEC (green). Integrated air-sea freshwater flux, or precipitation minus evaporation, over the same box and accumulated from 16 January 2013 from ERA-Interim (continuous black line) and from NCEP (discontinuous black line) databases.

argued that this new cooling period is led by the reduced ocean heat transport convergence resulting from a long-term slowdown of the AMOC. Within this long-term cooling period, we will focus hereafter on the pronounced heat content drop that happened between 2013 and 2014.

The negative anomalies of $\theta$ and $S$ in the surface intermediate layers along the OVIDE section in May-June 2014 with respect to the mean 2002-2012 were actually present over the whole of the year 2014 and the whole SPNA (Fig. 10). The $\theta$ and $S$ anomalies in the ocean can be caused by changes in the lateral advection of water masses with different properties and/or by anomalous net air-sea fluxes. Considering the high ocean heat transport observed during GEOVIDE, we analyzed the air-sea flux anomalies. The mean winterspring (W-S 2014) anomalies of air-sea heat flux presented strong negative anomalies over the whole SPNA (Fig. 11a); i.e., the ocean lost more heat than the 2002-2012 average with the contribution of both sensible and latent air-sea heat fluxes (Fig. 11b and c). The spatial repartition of the freshwater budget is mainly driven by the patterns of the precipitation anomalies, with a net freshwater loss southwest of the region and a clear gain in the eastern side. When the net freshwater flux was integrated over our region (Fig. 12), the net freshwater gain (Fig. 11d) shows that high precipita- tion rates (Fig. 11f) overcame the freshwater loss by evaporation (Fig. 11e). These anomalous air-sea heat and freshwater fluxes in the eastern SPNA suggest that the negative $\theta$ and $S$ anomalies observed in the surface intermediate waters during GEOVIDE were mainly formed locally by atmospheric forcing.

The heat and freshwater content changes in the upper $1000 \mathrm{~m}$ of the ocean during the 2013-2014 period were evaluated together with the air-sea heat and freshwater fluxes in the region delimited by $40-60^{\circ} \mathrm{N}$ latitude and $45-10^{\circ} \mathrm{W}$ longitude. In agreement with Grist et al. (2015), we found that the air-sea heat flux is responsible for most of the cooling observed in the surface intermediate layers. We estimated the accumulated air-sea heat loss from summer 2013 to summer 2014 at $6.8 \times 10^{21} \mathrm{~J}$, while the accumulated ocean heat loss for the same period amounted to $4.8 \times 10^{21} \mathrm{~J}$ (averaged of ISAS, EN4, and JAMSTEC estimates). This result is also in agreement with the findings of Duchez et al. (2016), who argued the 2013-2015 intense air-sea heat fluxes drove water masses transformation, which is an irreversible process. Recently, Frajka-Williams et al. (2017) explained that such short-term cooling is mainly caused by the atmospheric forcing since the hypothetical slowdown of the AMOC would take longer to generate a cooling of this magnitude. Concern- 
ing the freshwater, we detected that, despite the variability in freshwater content change on intra-seasonal and seasonal timescales (Fig. 12), there is good agreement between the trends shown by the ocean freshwater content and the airsea freshwater flux over the 2013-2014 period. We are aware of the large uncertainty associated with the air-sea freshwater flux (Josey and Marsh, 2005; Dee et al., 2011) and the ocean freshwater content. Therefore, we estimated both variables from two and three databases, respectively. The difference between the ERA-Interim and NCEP estimates of accumulated air-sea freshwater flux over the two years amount to $0.4 \times 10^{12} \mathrm{~m}^{3}$, while the ocean freshwater content estimates differ by $0.3 \times 10^{12} \mathrm{~m}^{3}$ (Fig. 12). We conclude that between 70 and $100 \%$ of the freshening observed in the considered volume of the SPNA is caused by air-sea freshwater inputs. These results support our conclusion that the negative $\theta$ and $S$ anomalies observed in the surface intermediate waters during the GEOVIDE cruise were locally formed by atmospheric forcing.

More evidence for the important role of air-sea fluxes is provided by the distribution of $\theta, S$, and oxygen anomalies in the water column. Indeed, the WMLD along the OVIDE section east of $20^{\circ} \mathrm{W}$ coincided with the deep limit of the anomalies (Fig. 7). It is somewhat more complex in the ERRC, where the WMLD crosses the anomaly separating subpolar mode water (SPMW) and upper Labrador Sea Water (LSW; see Fig. 2b); both water masses were advected together by the ERRC, but probably issued from different ventilation regions. According to de Boisséson et al. (2012), the SPMW is formed by air-sea interactions on its way around the Iceland Basin. The sign of all the anomalies described above is consistent with vertical mixing in the winter before the GEOVIDE cruise, transferring the cold, fresh, and oxygenated anomalies imprinted locally by the atmosphere into the whole mixed layer. In the Irminger Sea, the WMLD in Fig. 7 reaches $1200 \mathrm{~m}$ although deep convection did not exceed $700 \mathrm{~m}$ in winter 2014 in the central Irminger Sea (Piron, 2015; Duchez et al., 2016). It most likely results from the advection in the depth range 700-1200 m of high-oxygen intermediate water with densities slightly denser than the water above and possibly formed south of Greenland, as suggested by Fig. 5.3 of Piron (2015).

Below the orange line in Fig. 7, we observed mainly warming, salinification, and deoxygenation. This is in agreement with the tendencies observed since 2002 along the OVIDE section. Deep waters below $1300 \mathrm{~m}$ of depth in the Irminger Sea were obviously not recently renewed, apart from the plume of DSOW. Kieke and Yashayaev (2015) showed the evolution of $S$ and $\theta$ in the LSW measured in the Labrador Sea: below $1300 \mathrm{~m}$, the positive tendencies of $S$ and $\theta$ were similar to those observed in the Irminger Sea and concerned the dense LSW formed in the 1990s.

\section{Summary and conclusions}

This paper addresses two main issues: first, under the umbrella of the GEOTRACES program, it contextualizes the physical background of the GEOVIDE cruise carried out in May-June 2014, which is essential for the interpretation of the distribution of TEIs in the eastern SPNA. Second, it elucidates the cause of the cold and fresh anomaly detected in the surface waters of the eastern SPNA in May-June 2014.

Concerning the circulation across the OVIDE sections, the most important difference between the GEOVIDE state and the 2002-2012 mean state defined by D2016 is a strengthened Irminger Current and a weaker North Atlantic Current, with a possible transfer of volume transport from its northern branch to its central branch. The intensity of the MOC was the highest measured at the OVIDE section since 2002, $18.7 \pm 3.0 \mathrm{~Sv}$, and was high enough to compensate for the negative temperature anomaly detected in the surface waters, resulting in a high heat transport across the OVIDE section of $0.56 \pm 0.06 \mathrm{PW}$.

The special GEOVIDE stations where the trace elements were measured were indeed representative of the targeted hydrographic regions away from the core of the main advected eddies identified along the sections. Nevertheless, some precautions should be taken when comparing with previous years since the temperature, salinity, and oxygen of the SPNA winter mixed layer in 2014 were significantly different from the 2002-2012 mean.

Finally, we demonstrated that the cold and fresh anomalies in the 2014 mixed layer induced consistent changes in the heat and freshwater content of the SPNA. This strong 2013-2014 cooling is inserted in a long-term cooling in the SPNA that started in the mid-2000s. Our results elucidate the important role of air-sea flux in the $\theta-S$ changes in this region on a short timescale, overcoming the warming induced by the increase in the MOC amplitude and associated heat transport in May-June 2014.

Data availability. In addition to the data referenced in the paper that are publicly available, the GEOVIDE CTDO2 hydrographic and SADCP data were published by SEANOE (Lherminier and Sarthou, 2017). The 2014 Greenland-Portugal GEOVIDE CTDO2 hydrographic and SADCP data (GO-SHIP A25 and GEOTRACES GA01) are available at SEANOE: http://doi.org/10.17882/52153.

Competing interests. The authors declare that they have no conflict of interest.

Special issue statement. This article is part of the special issue "GEOVIDE, an international GEOTRACES study along the OVIDE section in the North Atlantic and in the Labrador Sea (GA01)". It is not associated with a conference. 
Acknowledgements. We gratefully acknowledge the crew of the R/V Pourquoi Pas? for their help and assistance during the cruise and with winch repairs. The GEOVIDE cruise would not have been achieved without the technical skills and commitment of Catherine Kermabon, Pierre Branellec, Philippe Le Bot, Olivier Ménage, Stéphane Leizour, Michel Hamon, Floriane Desprez de Gésincourt (LOPS), Fabien Pérault, and Emmanuel de Saint Léger (CNRS). We are particularly grateful to Géraldine Sarthou for her persistent dedication to the project and her precious advice as well as to the three anonymous reviewers who greatly helped us in improving the paper. The NCEP Reanalysis 2 data were provided by the NOAA/OAR/ESRL PSD in Boulder, Colorado, USA from their website at http://www.esrl.noaa.gov/psd/. The altimeter products were produced by Ssalto/Duacs and distributed by Aviso with support from CNES.

For this work, Patricia Zunino was supported by CNRS and IFREMER within the framework of the projects AtlantOS (European Union Horizon 2020, grant no. 633211) and GEOVIDE (ANR-13-BS06-0014-02). H. Mercier was financed by CNRS, Pascale Lherminier by Ifremer, and Nathalie Daniault by the University of Western Brittany, Brest. Maribel I. García-Ibáñez and Fiz F. Pérez were supported by the Spanish Ministry of Economy and Competitiveness through the BOCATS (CTM2013-41048-P) project co-funded by the Fondo Europeo de Desarrollo Regional 2014-2020 (FEDER).

Edited by: Gilles Reverdin

Reviewed by: three anonymous referees

\section{References}

Barrier, N., Deshayes, J., Treguier, A. M., and Cassou, C.: Heat budget in the North Atlantic subpolar gyre: Impacts of atmospheric weather regimes on the 1995 warming event, Prog. Oceanogr., 130, 75-90, https://doi.org/10.1016/j.pocean.2014.10.001, 2015.

Berrisford, P., Kallberg, P., Kobayashi, S., Dee, D., Uppala, S., Simmons, A. J., Poli, P., and Sato, H.: Atmospheric conservation properties in ERA-Interim, Q. J. R. Meteorol. Soc., 137, 13811399, https://doi.org/10.1002/qj.864, 2011.

Bersch, M.: North Atlantic Oscillation-induced changes of the upper layer circulation in the northern North Atlantic Ocean, J. Geophys. Res.-Ocean., 107, 1-11, https://doi.org/10.1029/2001JC000901, 2002

Bersch, M., Yashayaev, I., and Koltermann, K. P.: Recent changes of the thermohaline circulation in the subpolar North Atlantic, Ocean Dynam., 57, 223-235, https://doi.org/10.1007/s10236007-0104-7, 2007.

Bower, A. S. and von Appen, W. J.: Interannual variability in the pathways of the North Atlantic current over the Mid-Atlantic Ridge and the impact of topography, J. Phys. Oceanogr., 38, 104120, https://doi.org/10.1175/2007JPO3686.1, 2008.

Bryden, H. and Imawaki, S.: Ocean heat transport, in: Ocean Circulation and Climate, edited by: Siedler, G., Church, J., and Gould, J., Academic Press, 2001.

Cossa, D., Heimbürger, L.-E., Pérez, F. F., García-Ibáñez, M. I., Sonke, J. E., Planquette, H., Lherminier, P., and Sarthou, G.: Mercury distribution and transport in the North Atlantic Ocean along the GEOTRACES-GA01 transect, Biogeosciences Discuss., https://doi.org/10.5194/bg-2017-467, in review, 2017.

Daniault, N., Mercier, H., Lherminier, P., Sarafanov, A., Falina, A., Zunino P., Pérez, F. F., Rios, A. F., Ferron, B., Huck, T., Thierry, V., and Gladyshev, S.: The northern North Atlantic Ocean mean circulation in the early 21 st Century, Prog. Oceanogr., 146, 142158, https://doi.org/10.1016/j.pocean.2016.06.007, 2016.

de Boisséson, E., Thierry, V., Mercier, H., Caniaux, G., and Desbruyères, D.: Origin, formation and variability of the Subpolar Mode Water located over the Reykjanes Ridge, J. Geophys. Res.Ocean., 117, C12005, https://doi.org/10.1029/2011JC007519, 2012.

Dee, D. P., et al.: The ERA-Interim reanalysis: Configuration and performance of the data assimilation system, Q. J. R. Meteorol. Soc., 137, 553-597, https://doi.org/10.1002/qj.828, 2011.

Desbruyères, D., Mercier, H., and Thierry, V.: On the mechanisms behind decadal heat content changes in the eastern subpolar gyre, Prog. Oceanogr., 132, 262-272, https://doi.org/10.1016/j.pocean.2014.02.005, 2015.

Deshayes, J. and Frankignoul, C.: Simulated variability of the circulation in the North Atlantic from 1953 to 2003, J. Clim., 21, 4919-4933, https://doi.org/10.1175/2008JCLI1882.1, 2008.

Dickson, R. R., Meincke, J., Malmberg, S. A., and Lee, A. J.: The "great salinity anomaly" in the northern north Atlantic 1968-1982, Prog. Oceanogr., 20, 103-151, https://doi.org/10.1016/0079-6611(88)90049-3, 1988.

Duchez, A., Frajka-Williams, E., Josey, S. A., Evans, D. G., Grist, J. P., Marsh, R., McCarthy, G. D., Sinha, B., Berry, D. I., and Hirschi, J. J.-M.: Drivers of exceptionally cold North Atlantic Ocean temperatures and their link to the 2015 European heat wave, Environ. Res. Lett., 11, 1-9, https://doi.org/10.1088/17489326/11/7/074004, 2016.

Frajka-Williams, E., Beaulieu, C., and Duchez, A.: Emerging negative Atlantic Multidecadal Oscillation index in spite of warm subtropics, Sci. Rep., 7, 11224, https://doi.org/10.1038/s41598017-11046-x, 2017.

Gaillard, F., Reynaud, T., Thierry, V., Kolodziejczyk, N., and Von Schuckmann, K.: In Situ-Based Reanalysis of the Global Ocean Temperature and Salinity with ISAS: Variability of the Heat Content and Steric Height, J. Clim., 29, 1305-1323, https://doi.org/10.1175/JCLI-D-15-0028.1, 2016.

García-Ibáñez, M. I., Pardo, P. C., Carracedo, L. I., Mercier, H., Lherminier, P., Ríos, A. F., and Pérez, F. F.: Structure, transports and transformations of the water masses in the Atlantic Subpolar Gyre, Prog. Oceanogr., 135, 18-36, https://doi.org/10.1016/j.pocean.2015.03.009, 2015.

Good, S. A., Martin, M. J., and Rayner, N. A.: EN4: quality controlled ocean temperature and salinity profiles and monthly objective analyses with uncertainty estimate, J. Geophys. Res., 118, 6704-6716, https://doi.org/10.1002/2013JC009067, 2013.

Gourcuff, C., Lherminier, P., Mercier, H., and Le Traon, P. Y.: Altimetry Combined with Hydrography for Ocean Transport Estimation, J. Atmos. Ocean. Tech., 28, 1324-1337, https://doi.org/10.1175/2011JTECHO818.1, 2011.

Grist, J. P., Josey, S. A., Jacobs, Z. L., Marsh, R., Sinha, R., and Sebille, E. V.: Extreme air-sea interaction over the North Atlantic subpolar gyre during the winter of 20132014 and its subsurface legacy, Clim. Dynam., 46, 4027-4045, https://doi.org/10.1007/s00382-015-2819-3, 2015. 
Häkkinen, S., Rhines, P. B., and Worthen, D. L.: Warm and saline events embedded in the meridional circulation of the northern North Atlantic, J. Geophys. Res., 116, C03006, https://doi.org/10.1029/2010JC006275, 2011.

Hátún, H., Sandø, A. B., Drange, H., Hansen, B., and Valdimarsson, H.: Influence of the Atlantic subpolar gyre on the Thermohaline circulation, Science, 309, 1841-1844, https://doi.org/10.1126/science.1114777, 2005.

Hermanson, L., Eade, R., Robinson, N. H., Dunstone, N. J., Andrews, M. B., Knight, J. R., Scaife, A. A., and Smith, D. M.: Forecast cooling of the Atlantic subpolar gyre and associated impacts, Geophys. Res. Lett., 41, 5167-5174, https://doi.org/10.1002/2014GL060420, 2014.

Holliday, N. P., Cunningham, S. A., Johnson, C., Gary, S. F., Griffiths, C., Read, J. F., and Sherwin, T.: Multidecadal variability of potential temperature, salinity, and transport in the eastern subpolar North Atlantic, J. Geophys. Res.-Ocean., 120, 5945-5967, https://doi.org/10.1002/2015JC010762, 2015.

Hosoda, S., Ohira, T., and Nakamura, T.: A monthly mean dataset of global oceanic temperature and salinity derived from Argo float observations, JAMSTEC Rep. Res. Dev, 8, 47-59, 2008.

Hurrell, James and National Center for Atmospheric Research Staff (Eds.): The Climate Data Guide: Hurrell North Atlantic Oscillation (NAO) Index (station-based), available from: https://climatedataguide.ucar.edu/climate-data/ hurrell-north-atlantic-oscillation-nao-index-station-based, last access: 7 November 2017.

IPCC: Climate Change 2007: The Physical Science Basis, Contribution of Working Group I to the Fourth Assessment Report of the Intergovernmental Panel on Climate Change, edited by: Solomon, S., Qin, D., Manning, M., Chen, Z., Marquis, M., Averyt, K. B., Tignor, M., and Miller, H. L., Cambridge University Press, Cambridge, United Kingdom and New York, NY, USA, 996 pp., 2007.

Johnson, G. C., Lyman, J. M., Boyer, T., Domingues, C. M., Ishii, M., Killick, R., Monselesan, D., and Wijffels, S. E.: Ocean heat content, in: State of the Climate in 2015, Bull. Amer. Meteor. Soc., 97, S64-S65, 2016.

Josey, S. A. and Marsh, R.: Surface freshwater flux variability and recent freshening of the North Atlantic in the eastern subpolar gyre, J. Geophys.-Res., 110, C05008, https://doi.org/10.1029/2004JC002521, 2005.

Kalnay, E., Kanamitsu, M., and Kistler, R.: The NCEP/NCAR 40year reanalysis project, B. Am. Meteorol. Soc., 77, 437-470, 1996.

Kanamitsu, M., Ebisuzaki, W., Woollen, J., Yang, S.-K., Hnilo, J. J., Fiorino, M., and Potter, G. L.: NCEP-DOE AMIP-II Reanalysis (R-2), B. Am. Meteor. Soc., 83, 1631-1643, 2002.

Khatiwala, S., Tanhua, T., Mikaloff, Fletcher, S., Gerber, M., Doney, S. C., Graven, H. D., Gruber, N., McKinley, G. A., Murata, A., Rios, A. F., and Sabine, C. L.: Global ocean storage of anthropogenic carbon, Biogeosicences, 10, 2169-2191, https://doi.org/10.5194/bg-10-2169-2013, 2013.

Kieke, D. and Yashayaev, I.: Studies of Labrador Sea Water formation and variability in the subpolar North Atlantic in the light of international partnership and collaboration, Prog. Oceanogr., 132, 220-232, https://doi.org/10.1016/j.pocean.2014.12.010, 2015.
Kuhlbrodt, T., Griesel, A., Montoya, M., Levermann, A., Hofmann, M., and Rahmstorf, S.: On the driving processes of the Atlantic meridional overturning circulation, Rev. Geophys., 45, RG2001, https://doi.org/10.1029/2004RG000166, 2007.

Lemaitre, N., Planquette, H., Planchon, F., Sarthou, G., Jacquet, S., García-Ibáñez, M. I., Gourain, A., Cheize, M., Monin, L., André, L., Laha, P., Terryn, H., and Dehairs, F.: Particulate barium tracing significant mesopelagic carbon remineralisation in the North Atlantic, Biogeosciences Discuss., https://doi.org/10.5194/bg2017-400, in review, 2017.

Le Roy, E., Sanial, V., Charette, M. A., van Beek, P., Lacan, F., Jacquet, S. H. M., Henderson, P. B., Souhaut, M., García-Ibáñez, M. I., Jeandel, C., Pérez, F. F., and Sarthou, G.: The ${ }^{226}$ Ra-Ba relationship in the North Atlantic during GEOTRACES-GA01, Biogeosciences Discuss., https://doi.org/10.5194/bg-2017-478, in review, 2017.

Lherminier, P., Mercier, H., Gourcuff, C., Alvarez, M., Bacon, S., and Kermabon, C.: Transports across the 2002 GreenlandPortugal Ovide section and comparison with 1997, J. Geophys. Res., 112, C07003, https://doi.org/10.1029/2006JC003716, 2007.

Lherminier, P., Mercier, H., Huck, T., Gourcuff, C., Pérez, F. F., Morin, P., Sarafanov, A., and Falina, A.: The Atlantic Meridional Overturning Circulation and the subpolar gyre observed at the A25-OVIDE section in June 2002 and 2004, Deep-Sea Res. Pt. I, 57, 1374-1391, https://doi.org/10.1016/j.dsr.2010.07.009, 2010.

Lherminier, P. and Sarthou G.: The 2014 Greenland-Portugal GEOVIDE CTDO2 hydrographic and SADCP data (GO-SHIP A25 and GEOTRACES GA01), SEANOE, available at: http://doi.org/ 10.17882/52153, 2017.

Levitus, S., Antonov, J. I., Boyer, T. P., Baranova, O. K., Garcia, H. E., Locarnini, R. A., Mishonov, A. V., Reagan, J. R., Seidov, D., Yarosh, E. S., and Zweng, M. M.: World ocean heat content and thermosteric sea level change (0-2000 m), 1955-2010, Geophys. Res. Let., 39, L10603, https://doi.org/10.1029/2012GL051106, 2012.

Lohmann, K., Drange, H., and Bentsen, M.: Response of the North Atlantic subpolar gyre to persistent North Atlantic Oscillation like forcing, Clim. Dynam., 32, 273-285, https://doi.org/10.1007/s00382-008-0467-6, 2009.

Lux, M., Mercier, H., and Arhan, M.: Interhemispheric exchanges of mass and heat in the Atlantic Ocean in January-March 1993, Deep-Sea Res. Pt. I, 48, 605-638, 2001.

Marsh, R., Josey, S. A., de Cuevas, B. A., Redbourn, L. J., and Quartly, G. D.: Mechanisms for recent warming of the NorthAtlantic: Insights gained with an eddy-permitting model, J. Geophys. Res., 113, C04031, https://doi.org/10.1029/2007JC004096, 2008.

Mercier, H.: Determining the general circulation of the ocean: a non linear inverse problem, J. Geophys. Res., 91, 5103-5109, https://doi.org/10.1029/JC091iC04p05103, 1986.

Mercier, H., Lherminier, P., Sarafanov, A., Gaillard, F., Daniault, N., Desbruyères, D., Falina, A., Ferron, B., Gourcuff, C., Huck, T., and Thierry, V.: Variability of the meridional overturning circulation at the Greenland-Portugal OVIDE section from 1993 to 2010, Prog. Oceanogr., 132, 250-261, https://doi.org/10.1016/j.pocean.2013.11.001, 2015.

Pérez, F. F., Vázquez-Rodríguez, M., Mercier, H., Velo, A., Lherminier, P., and Ríos, A. F.: Trends of anthropogenic $\mathrm{CO}_{2}$ storage 
in North Atlantic water masses, Biogeosciences, 7, 1789-1807, https://doi.org/10.5194/bg-7-1789-2010, 2010.

Pérez, F. F., Mercier, H., Vázquez-Rodríguez, M., Lherminier, P., Velo, A., Pardo P. C., Rosón, G., and Ríos, A. F.: Atlantic Ocean $\mathrm{CO}_{2}$ uptake reduced by weakening of the meridional overturning circulation, Nat. Geosci., 6, 146-152, https://doi.org/10.1038/NGEO1680, 2013.

Piron, A.: Observation de la convection profonde en mer d'Irminger sur la période 2002-2015 par les flotteurs Argo, PhD Thesis, Université de Bretagne Occidentale, http://archimer.ifremer.fr/ doc/00313/42434/, 2015.

Rhein, Monika., Kieke, D., Hüttl-Kabus, S., Roessler, A., Mertens, C., Meissner, R., Klein, B., Böning, C. W., and Yashayaev, I.: Deep water formation, the subpolar gyre, and the meridional overturning circulation in the subpolar North Atlantic, Deep-Sea Res. Pt. II, 58, 1819-1832, https://doi.org/10.1016/j.dsr2.2010.10.061, 2011.

Riser, S. C., Freeland, H. J., Roemmich, D., Wijffels, S., Troisi, A., Belbeoch, M., Gilbert, D., Xu, J., Pouliquen, S., Ann, T., Le Traon, P. Y., Maze, G., Klein, B., Ravichandran M., Grant, F., Poulain, P. M., Suga, T., Lim, B., Sterl. A., Sutton, P., Mork, K. A., Velez-Belch, J. P., Ansorge, I., King, B., Turton, J., Baringer, M., and Jayne, S. R.: Fifteen years of ocean observations with the global Argo array, Nature Climate Change, 6, 145-153, https://doi.org/10.1038/NCLIMATE2872, 2016.

Robson, J., Sutton, R., Lohmann, K.,Smith., D., and Palmer, M.: Causes of the Rapid Warming of the North Atlantic Ocean in the Mid-1990s, J. Clim., 25, 4116-4134, https://doi.org/10.1175/JCLI-D-11-00443.1, 2012.

Robson, J., Sutton, R., and Smith, D.: Decadal predictions of the cooling and freshening of the North Atlantic in the 1960s and the role of ocean circulation, Clim. Dynam., 42, 2353-2365, https://doi.org/10.1007/s00382-014-2115-7, 2014.

Robson, J., Ortega, P., and Sutton, R.: A reversal of climatic trends in the North Atlantic since 2005, Nat. Geosci., 9, 513-517, https://doi.org/10.1038/NGEO2727, 2016.

Robson, J., Polo, I., Hodson, D. L. R., Stevens, D. P., and Shaffrey, L. C.: Decadal prediction of the NorthAtlantic subpolar gyre in the HiGEM highresolution climate model, Clim. Dynam., 1-17, https://doi.org/10.1007/s00382-017-3649-2, 2017.

Rossby, T., Reverdin, G., Chafik, L., and Søiland, H.: A direct estimate of poleward volume, heat, and freshwater fluxes at $59.58^{\circ} \mathrm{N}$ between Greenland and Scotland, J. Geophys. Res.-Ocean., 122, 5870-5887, https://doi.org/10.1002/2017JC012835, 2017.
Sarafanov, A., Falina, A., Sokov, A., and Demidov, A.: Intense warming and salinification of intermediate waters of southern origin in the eastern subpolar North Atlantic in the 1990s to mid-2000s, J. Geophys. Res., 113, C12022, https://doi.org/10.1029/2008JC004975, 2008.

Sarafanov, A., Falina, A., Mercier, H., Sokov, A., Lherminier, P., Gourcuff, C., Gladyshev, S., Gaillard, F., and Daniault, N.: Mean full-depth summer circulation and transports at the northern periphery of the Atlantic Ocean in the 2000s, J. Geophys. Res.Ocean., 117, C01014, https://doi.org/10.1029/2011JC007572, 2012.

Sgubin, G., Swingedouw, D., Drijfhout, S., Mary, Y., and Bennabi, A.: Abrupt cooling over the North Atlantic in modern climate models, Nat. Commun., 8, 14375, https://doi.org/10.1038/ncomms14375, 2017.

Spall, M. A. and Price, J. F.: Mesoscale Variability in Denmark Strait: The PV Outflow Hypothesis, J. Phys. Oceanogr., 28, 1598-1623, 1997.

Tonnard, M., Sarthou, G., Gallinari, M., Boutorh, J., Cheize, M., Contreira, Menzel, J.-L., Shelley, R., Claustre, H., Lherminier, P., and Planquette, H.: Dissolved iron distribution in the North Atlantic Ocean and Labrador Sea along the GEOVIDE section, Biogeosciences Diss., in preparation, 2017.

Väge, K., Pickart, R. S., Sarafanov, A., Knutsen, O., Mercier, H., Lherminier, P., van Aken, H. M., Meincke, J., Quadfasel, D., and Bacon, S.: The Irminger Gyre: Circulation, convection, and interannual variability, Deep-Sea Res. Pt. I, 58, 590-614, https://doi.org/10.1016/j.dsr.2011.03.001, 2011.

Williams, R., Roussenov, V., Smith, D., and Lozier, S.: Decadal evolution of ocean thermal anomalies in the North Atlantic: The effects of Ekman, Overturning, and Horizontal Transport, J. Clim., 27, 698-719, https://doi.org/10.1175/JCLI-D-12-00234.1, 2014.

Yashayaev, I. and Loder, J. W.: Recurrent replenishment of Labrador Sea Water and associated decadal scale variability, J. Geophys. Res.-Ocean., 121, 8095-8114, https://doi.org/10.1002/2016JC012046, 2016.

Yashayaev, I. and Loder J. W.: Further intensification of deep convection in the Labrador Sea in 2016, Geophys. Res. Lett., 44, 1429-1438, https://doi.org/10.1002/2016GL071668, 2017.

Zunino, P., Pérez, F. F., Fajar, N. M., Guallart, E. F., Ríos, A. F., Pelegrí, J. L., and Hernández-Guerra, A.: Transports and budgets of anthropogenic $\mathrm{CO}_{2}$ in the tropical North Atlantic in 19921993 and 2010-2011, Global Biogeochem. Cy., 29, 1075-1091, https://doi.org/10.1002/2014GB005075, 2015. 